\title{
"We would never go back" \\ Stories of early years teachers \\ transitioning \\ to play-based learning environments
}

BY

TERESA MAGUIRE

A thesis

submitted to the Victoria University of Wellington

in fulfilment of the requirements for the degree of

Master of Education

Victoria University of Wellington

2020 


\section{Acknowledgements}

I would like to thank my husband, David, for his support, encouragement, and proofreading skills during this research.

I would also like to thank the senior leadership team and staff of NZCER for their support, advice, and on-going interest in my research.

Thank you also to Judith Loveridge for her mentorship during the process of researching and writing this thesis.

Finally, I would like to thank the teachers who participated in this study for giving up their time. I wish you well in your journeys.

Ngā mihinui koutou 


\section{Contents}

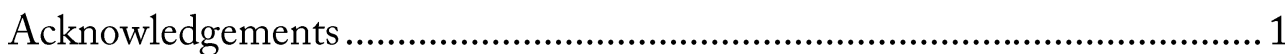

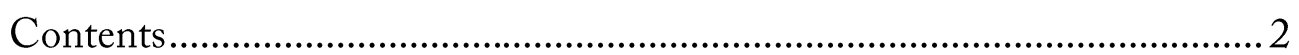

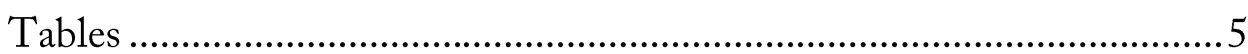

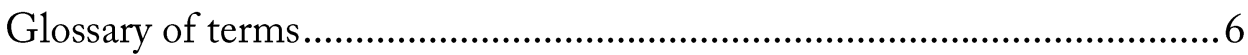

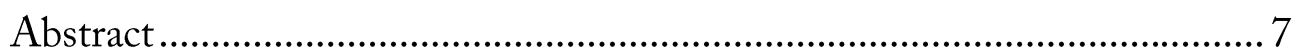

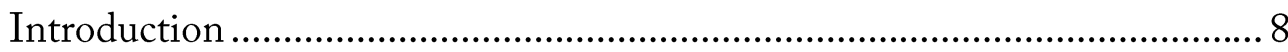

Introducing the researcher....................................................................... 8

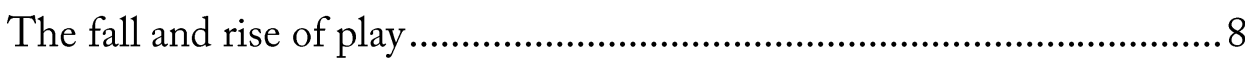

The structure of this thesis report ..............................................................12

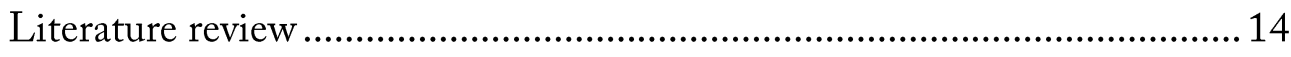

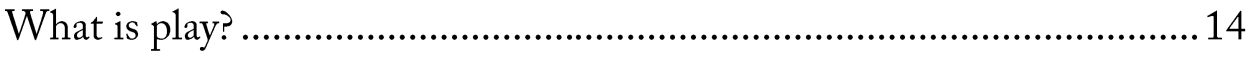

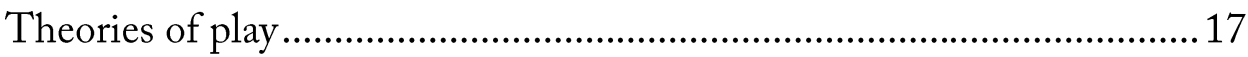

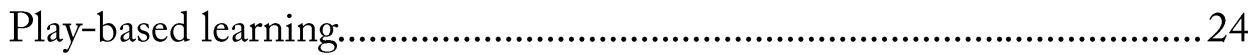

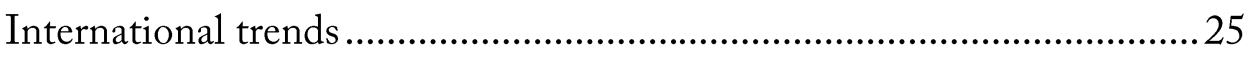

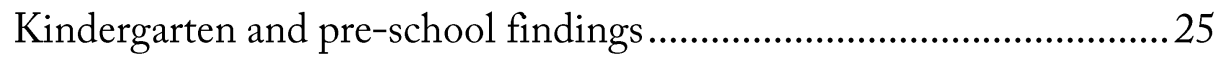

Primary school findings ....................................................................22

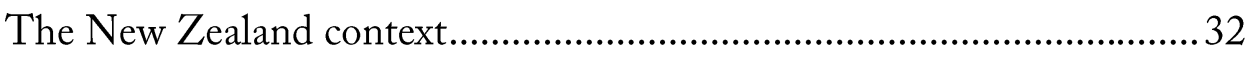




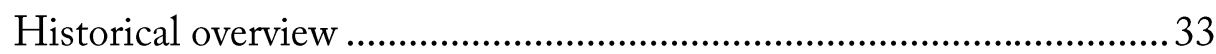

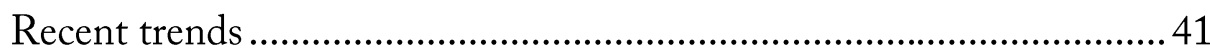

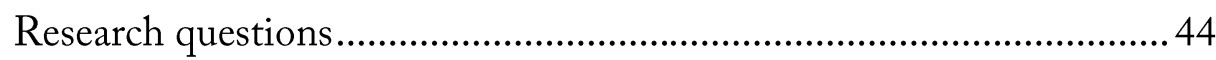

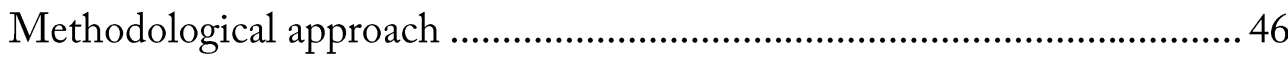

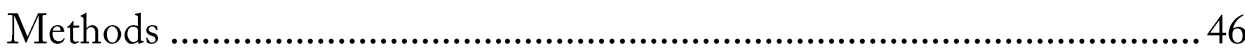

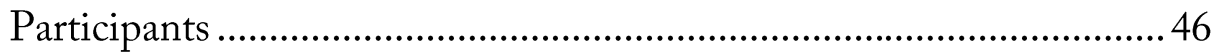

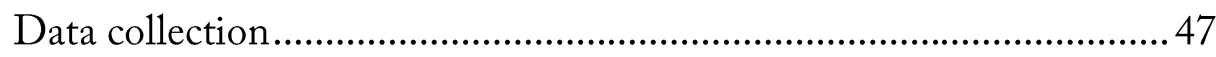

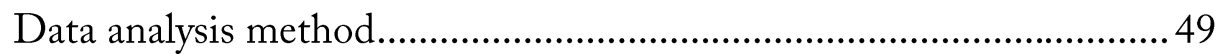

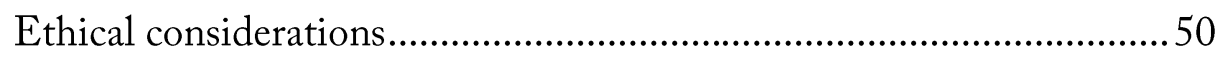

Reliability and validity ....................................................................... 50

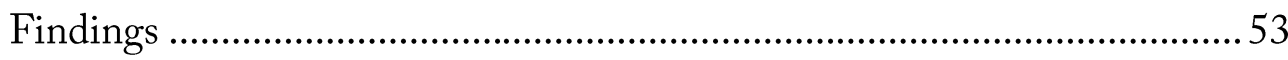

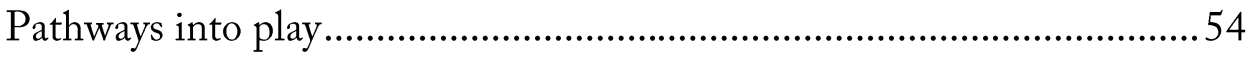

Reasons for transitioning to play-based learning .......................................6 60

Teachers have changed their practices .........................................................63

Adaptations to the teaching environment .............................................63

Adaptations to teaching programmes...................................................66

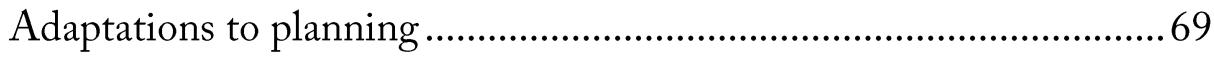

Assessment in a play-based classroom................................................... 72 
Teachers have changed their beliefs about teaching and learning 76

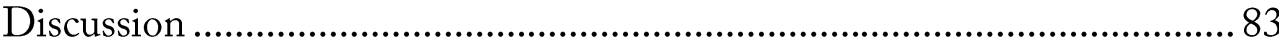

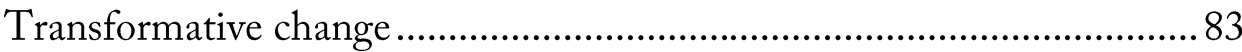

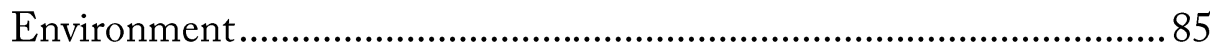

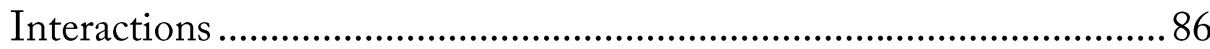

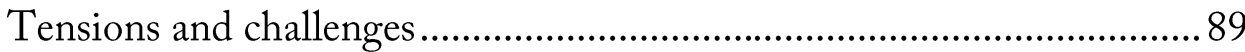

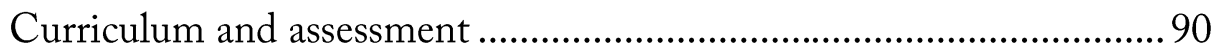

Colleagues, management and parents ...............................................92

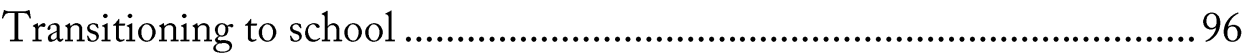

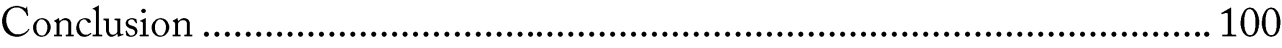

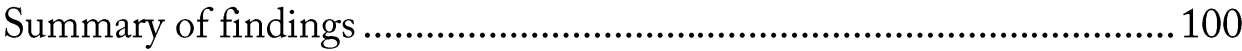

What pathways have teachers taken in their transition to a play-based

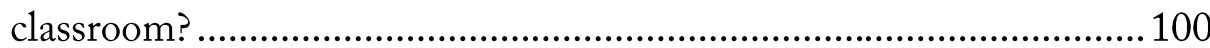

What are the reasons teachers of students in years one to three are transitioning from traditional to play-based classrooms? 100

What changes in practice have teachers made as a result of this transition? 
What changes in beliefs about themselves as teachers have occurred as a

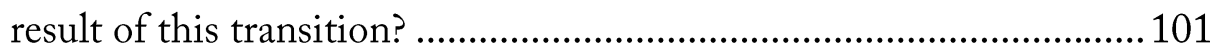

Implications for policy and practice ........................................................101

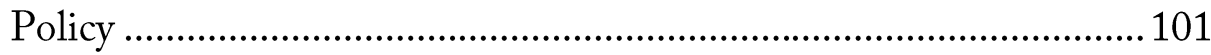

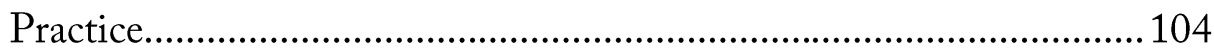

Strengths and limitations of this research ..............................................106

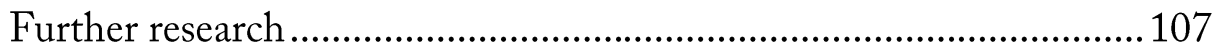

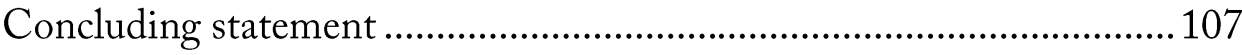

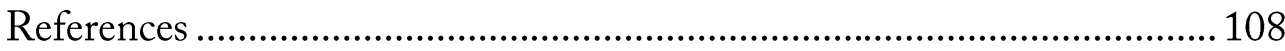

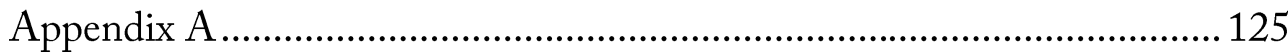

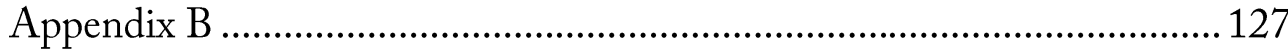

\section{Tables}

Table 1: Thematic analysis phases ............................................................... 50

Table 2: Summary of participants and their classroom set ups...................... 54

Table 3: Types of play areas observed ............................................................ 64 


\section{Glossary of terms}

Back planning: Teachers plan retrospectively by noticing and observing the learning occurring within children's play and connecting that learning to the curriculum.

Intentional teaching: Teachers make informed decisions about the learning environment, play supports, and their interactions with students.

Invitations to play: The environment and deliberately selected artefacts provided by teachers for play.

Play-based learning: Play that can be either child-initiated or teacher-guided. Teachers take an active role by noticing, recognising and responding to the students.

Provocations: Teacher responses to the observed interests and urges of children at play. 


\section{Abstract}

International and national interest has been growing around the use of play-based learning approaches in the early years of primary school. This qualitative study explored the journeys of five early years teachers in New Zealand, who were transitioning to using play-based learning approaches in their classrooms. Semi-structured interviews and observations of teacher interactions were used to explore the reasons teachers were moving away from traditional teaching practices, the pathways they were taking, and the changes they had made in both their practices and their beliefs about themselves as teachers. Findings indicated that teachers in this study adopted play-based learning approaches because they were more appropriate for their students' learning and development. They had initiated the move to play-based learning themselves, often with the support of a fellow teacher. School leaders and other colleagues were both understanding of, and resistant to, the changes the teachers were making. Teachers had adapted the physical environment of their classroom to accommodate play-based practices. More significantly, however, they had transformed the way they perceived themselves and their role in the classroom. This grassroots movement towards implementing play-based learning approaches in schools has implications for curriculum, assessment, resourcing, and preschool primary transitions. 


\section{Introduction}

\section{Introducing the researcher}

I became interested in play-based learning during the second half of my 17-year primary teaching career. I was teaching students in years two and three and had begun to incorporate elements of a play-based approach into my teaching. I noticed that my students seemed to thrive when given opportunities to make choices for themselves or to engage in playful, exploratory learning. I noticed how much I enjoyed these sessions, and how they felt more appropriate for the learning and development of five to seven-year old students. Simultaneously, colleagues began to share anecdotes suggesting that the oral language skills of five-year olds had decreased, and students were struggling with the transition to the academic demands of school. I felt that students in this age group were not always ready for the formal teaching and assessment that was expected of them. This led me to question the ways these young learners were being taught. I began to read about how and why using play-based approaches in the classroom could benefit students.

\section{The fall and rise of play}

The last decade has seen an increasing amount of research written about play and play-based learning. From Miller and Almon's seminal 2009 paper on the crisis in American kindergartens (Miller \& Almon, 2009) through to the 2019 book Let the Children Play (Sahlberg \& Doyle, 2019), the story has remained the same. Educators, researchers, and parents worldwide have become increasingly concerned about the 
decline in children's spontaneous, unsupervised play, particularly in the outdoors (Beck, 2019; Entin, 2011). This decline has occurred for a variety of reasons, including technological changes, economic pressures, and cultural shifts. An increased push for earlier academic achievement, believing that it leads to later success at school, is a further reason for this decline (Beck, 2019, Yogman, Garner, Hutchinson, Hirsh-Pasek \& Golinkoff, 2018).

These concerns have triggered what Whitebread (2018) termed a "renaissance" of interest in play, evidenced by the creation of the International Journal of Play in 2018, and a “...plethora of recent academic publications" across a range of disciplines (p. 237). Many of these publications articulate the benefits of play for the physical, social, cognitive, and, crucially, the emotional development of young children (Gray, 2015; Sahlberg \& Doyle, 2019). Recent developments in the field of neuroscience have also reinforced the importance of play for brain development, particularly in early childhood (Beck, 2019; Liu et al., 2017; Zosh et al., 2017). One clear message that comes through is that play is a more appropriate way for children to learn and develop, and should be the main approach taken by teachers of young students.

New Zealand has not been immune to these global trends. In her article on bringing play back into the classroom, Menzies (2015) observed that "...children have more structure and organisation in their lives than ever before...[with] fewer opportunities for play within their classrooms..." (para. 4). The push to increase academic achievement was accelerated in 2010 with the introduction of National Standards. Primary schools were required to assess and report on their students against benchmarked achievement levels in literacy and numeracy. This reporting included students who had been at school for as little as six 
months. Teachers and school leaders shifted their focus towards these narrowly defined areas of academic success, to the detriment of both the wider curriculum (Bonne, 2016), and the inclusion of play in early years classrooms. During the 2017 revision of New Zealand's early childhood curriculum, Te Whäriki (Ministry of Education, 2017), critics expressed concern about the "pushing down" of academic achievement into the realm of preschool education. Criticism included the shift towards a narrower set of learning outcomes, the use of more formal teaching and assessment approaches usually associated with schools (Haggerty \& Loveridge, 2019), and an increased emphasis on literacy and numeracy (Barber, 2019).

Decreased opportunities for play have coincided with increases in "...anxiety, depression, and problems of attention and self-control" (Entin, 2011, para. 3) among young people. The Office of the Director of Mental Health and Addiction Services in New Zealand (Ministry of Health, 2019) noted that "in the 2017 calendar year, a record number of people accessed specialist mental health and addiction services" (p. xi). Neuroscience educator Nathan Wallis, when interviewed about reasons for New Zealand's high youth suicide rate, commented that "in the last fifteen years, we've wanted to teach our three, four, five-year-olds literacy and numeracy instead of doing the free play that would build up resilience..." (McIvor, 2019, para. 9). Schools are increasingly concerned about the mental welfare of their students, with both the New Zealand Council for Educational Research (NZCER) (Boyd \& Barwick, 2011) and the Education Review Office (ERO) (2015b) publishing reports on ways that schools can improve student wellbeing. Both reports emphasise the importance of developing students' social and emotional competencies as part of this improvement. 
Schools in New Zealand are experiencing a play "renaissance". Evidence of this comes from several articles on play-based learning published in a recent special edition of Set: Research Information for teachers (Bolstad \& Roberts, 2018). A growing concern about the comparatively low school starting age in New Zealand is one of the influencing factors in this resurgence. Globally, most children start formal schooling between the ages of six and eight, however, due to “...historical and societal expectations...” (Hedges, 2018, p. 61), rather than developmental needs, students in New Zealand most commonly start on, or near, their fifth birthday.

The idea that an early start gives students an academic advantage is not supported by the research. Suggate, in Suggate and Reese (2012) examined studies where the reading achievement of students who began formal literacy learning at different ages was compared. They found that "...there was no advantage for the children learning to read early and even a slight, statistically significant, edge in reading comprehension for the later readers" (p. 188). Suggate also suggested that a focus on early reading interventions might have unintended consequences "...such as demotivating children or taking them away from activities that could be more beneficial for their...development (such as language, social interaction, imaginative development, or play)" (p. 183). Supporting this position, Marcon's (2002) longitudinal study compared the academic success of students from three different preschool environments - "child-initiated", "academically focused", and "middle-of-the-road" classrooms. She concluded that "Children's later school success appears to be more enhanced by more active, child-initiated learning experiences" while “...long-term progress may be slowed by overly academic preschool experiences" (p. 20). She noted that "pushing children too soon may 
actually backfire..." (pp. 20-21) as they can struggle when they move to higher grades and have to become more responsible for their own learning.

With the demise of National Standards in 2017, and the growing awareness among primary teachers and school leaders in New Zealand of the potentially detrimental impact of requiring young students to participate in formal learning before they are ready, teachers have begun to bring play-based learning back into their classrooms. This shift towards making schools ready for students, rather than making students ready for school, coupled with my own experiences of students and play has led me to wonder how teachers have been implementing play-based learning in their classrooms and what challenges they have encountered. This study explores the changes that New Zealand teachers of year one students have made to their practices and beliefs as a result of adopting play-based learning approaches in their classrooms.

\section{The structure of this thesis report}

This report consists of six sections, including this introduction. Section two reviews the literature on play. It commences with examining definitions and theories of play, and then goes on to analyse international trends in both pre-school and school settings. A succinct historical overview of aspects of the New Zealand schooling system is provided, followed by a brief account of recent developments. The section finishes with an outline of the four research questions.

In the third section, the methodological approach is outlined, followed by an explanation of the chosen methodology, data collection, 
and analysis. The section concludes by discussing ethical considerations, research reliability, and validity.

The fourth section provides the detailed findings of this study using the framework of the four research questions. It explores pathways into play, reasons for transitioning to play, and the ways that teachers have changed their practices and beliefs about teaching and learning.

The fifth section presents a discussion of the findings by looking at the transformations that teachers have made and the tensions and challenges they have faced.

The conclusion summarises the study and explores the implications for policy, practice, and research. 


\section{Literature review}

\section{What is play?}

This review of the literature will confine itself to definitions that include common characteristics of play rather than those that offer a taxonomy of play. There are many ways to describe play, and researchers agree that play is a difficult concept to define (Gray, 2015; Sahlberg \& Doyle, 2019; Wallerstedt \& Pramling, 2012). Davis (2018, p. 30) calls it a "slippery thing". One of the difficulties in defining play is that it can appear contradictory, “...serious yet not serious; trivial yet profound; imaginative and spontaneous, yet bound by rules and anchored in the real world" (Gray, 2015, p. 139). The variety of perspectives from which play has been examined - biological, cognitive, behavioural and physiological (Burghardt, 2010) have also contributed to issues of definition. Sahlberg and Doyle (2019) suggest that there are as many definitions of play as there are advocates. Despite these difficulties there are some common elements that can be found in the literature that define and describe play. Wallerstedt and Pramling (2012) liken these commonalities to similarities that might be found amongst family members.

Play is considered to be a pleasurable, fun, and enjoyable activity (Pyle \& Danniels, 2017; Whitebread, 2018; Wood, 2013). In some Scandinavian languages, the words for unstructured types of play differ from those used for playing a sport or an instrument. Leikki, the Finnish word for substantive play, is translated as "action done for fun, especially among children" (Sahlberg \& Doyle, 2019, p. 49). We tend to think of children being joyful when they are playing, although the contradictory nature of play means that play can also have its serious 
side. In play a child may feel serious when they are playing or the content of their play may be serious (National Playing Fields Association, 2000). Play may also include elements of frustration, challenge, or fear (Barblett, 2010).

Another characteristic of play is its voluntary nature. Play is a selfchosen activity that is led or directed by the child (Caillois, 1962; Miller \& Almon, 2009; Pyle \& Danniels, 2017; Rieber, 1996). When children play it is because they want to play, not because they feel obliged to play (Gray, 2015). Children choose how to play, what to play (Ashiabi, 2007) and, most importantly, they choose when they want to leave the play (Brewer, 2007; Caillois, 1962). As Gray (2015) puts it, “...the ultimate freedom in play is the freedom to quit" (p. 141).

Gray also argues that the characteristics of play have more to do with motivation and mental attitude than they do with behaviour. Most researchers agree that play is intrinsically motivated (Davis, 2018; Fleer, 2013; Miller \& Almon, 2009; Wood, 2013) while Burghardt (2010) defines play as autotelic, something that is done for its own sake. The act of playing itself provides the benefit (Sahlberg \& Doyle, 2019) and there are no external goals or rewards for the players (Brewer, 2007; National Playing Fields Association, 2000). Wallerstedt and Pramling (2012) talk about play having a lack of purpose or being aimless while Caillois (1962) comments that play is seen to be unproductive. Burghardt (2010), however, argues that play should be considered as “...not fully functional..." (p. 8) rather than having no immediate use or purpose. In play, children are motivated by the means rather than the ends (Gray, 2015). It is the process of playing that is important not the product (Barblett, 2010; Pyle \& Danniels, 2017; Sahlberg \& Doyle, 2019). Play is an important activity in its own right 
(Wood, 2013) and the meaning is supplied by the players through their own interpretation of materials (Brewer, 2007). Morgan and Kennewell (2006) endorse this idea of the activity being more important than the achievement and suggest that the process involved is often social.

Play has also been characterised by its being imaginative and creative (Ashiabi, 2007; Gray, 2015), spontaneous (Caillois, 1962; Wallerstedt \& Pramling, 2012), and having elements of make-believe or pretence (Rieber, 1996; Sahlberg \& Doyle, 2019; Wood, 2013). Play is considered to be nonliteral and removed from real life (Burghardt, 2010; Gray, 2015; Sahlberg \& Doyle, 2019). Children play "as if" (Pramling Samuelsson \& Johansson, 2006) or "what if" (Barblett, 2010). Another feature of play is that there are almost always rules and structures which govern how the play proceeds (Brewer, 2007; Caillois, 1962; Gray, 2015). These rules are determined by the players and all who play must agree to the rules (Caillois, 1962; Gray, 2015). Researchers and theorists propose that this aspect of play helps children to develop self-control. Children want to keep playing and to do so they have to follow the agreed-upon rules. They subsume their own impulses and desires in order to continue the play and in this way learn to control their emotions (Caillois, 1962; Gray, 2015).

The final characteristic of play considered here is that it is more about the participants, or the players, rather than the play itself. Burghardt (2010) and Gray (2015) both state that participants in play need to be in a relaxed state and not stressed. Burghardt (2010) argues that children need to be well-fed, clothed, healthy and out of danger in order to participate in play, although when children play in war zones or refugee camps, for example, they may not necessarily have all these requirements. Gray (2015) notes that participants require “...an active, 
alert mind" (p. 152). This active involvement could be physical, mental or verbal (Barblett, 2010). When describing play Wallerstedt and Pramling (2012) use words such as "manipulation", "exploration" and "problem-solving" which indicate that the participant takes an active role. Ashiabi (2007) and Pyle and Danniels (2017) both talk about play as being actively engaging. It is not something passive that happens to the child (Brewer, 2007) but is something that the child is absorbed or engrossed in.

In addition to exploring definitions of play, it is also useful to delve into the theories of play.

\section{Theories of play}

A number of theorists have examined play and its role in human development. This section provides a brief overview of some of the more well-known play theorists. These theories offer different ways to analyse or think about play and can guide us in determining what we focus on when we observe play situations (Fleer, 2013). In addition, it is possible to see connections between theoretical understandings of play and the way in which organised schools and curricula are organised and constructed.

An early group, that Fleer (2013) calls the "classical theorists", developed their ideas about play in the late nineteenth and early twentieth centuries. This group included Herbert Spencer (1820-1903), Moritz Lazarus (1824-1903), Karl Groos (1861-1946), and G. Stanley Hall (1846-1924). The theories of Spencer and Lazarus are sometimes referred to as "Energy regulation theories" (Brock, 2014, p. 9). Spencer believed that higher order animals, including humans, accumulated excess energy and needed a way to "let off steam" or release this 
energy, which was through play (Brock, 2014). Play was aimless (Fleer, 2013), had no ulterior benefits, and was carried out "for the sake of the immediate gratifications involved" (Smith, Cowie \& Blades, 2011, p. 247). Lazarus, on the other hand, theorised that play was a way to restore energy that had been lost through working (Brock, 2014). His view was that work took a lot of energy and there was a need for rest and sleep. Play was initiated because of the need for relaxation. Playing and recreating would have the effect of restoring lost energy (Fleer, 2013).

Groos disagreed with Spencer and felt that play had a more defined function than merely releasing surplus energy (Brock, 2014). He thought that while excess energy might set up positive conditions for play, it was not essential (Smith et al., 2011). His "practice" or "exercise" theory of play posited that the main reason for childhood was for children to play and that through play young animals, and children, would learn and practice the skills they needed for adulthood (Brock, 2014). Groos also developed an early categorisation of play, identifying stages of play which changed as the child developed (Brock, 2014). Hall disagreed with Groos (Fleer, 2013) and felt his theory was "very partial, superficial, and perverse" (Smith et al., 2011, p. 248). He perceived childhood as a "link between the animal and human ways of thinking" (Brock, 2014, p. 10) and saw play as a way for humans to work through four stages of the evolutionary process which he identified as animal, savage, tribal society, and modern society (Brock, 2014; Smith et al., 2011). His "recapitulation theory", however, has been seen as racist, and discredited as understandings about human instincts and behaviours have moved on (Brock, 2014; Smith et al., 2011). 
The early twentieth century psychoanalyst, Sigmund Freud (18561939), had ideas about child development and play that have influenced some aspects of education. Freud felt that play provided a safe place for children to express impulses that they could not let out in reality (Brock, 2014; Smith et al., 2011). In addition he believed that not only was play a place where children could express their wishes and anxieties, but it was also through play that children could get rid of negative feelings that had developed as a result of trauma (Brock, 2014; Smith et al., 2011). His ideas were progressed further by his peers and successors in the psychoanalytic field who developed "play therapy", an approach used mainly with young children to help them explore their feelings and work through traumatic events in a safe, comfortable environment (Brock, 2014; Smith et al., 2011).

Jean Piaget's (1895-1980) theories and understandings about young children's learning have had a significant impact in many educational contexts (Fleer, 2013; Smith et al., 2011). Piaget viewed play not as a behaviour, but as a state of mind, or an orientation (Fleer, 2013; National Playing Fields Association, 2000). He believed that play was internally motivated and children carried it out for pleasure (Fleer, 2013; National Playing Fields Association, 2000). Piaget disputed the "practice" or "exercise" theory of play as he observed children in play carrying out activities that did not require practice, such as sleeping (Smith et al., 2011).

Play forms an integral component of each of the first three cognitive developmental stages of Piaget's child development theory (Fleer, 2013). Practice play, where actions are repeated over and over again, is typical of children in the sensorimotor stage (birth to 2 years), while symbolic play, when children are able to imagine something that 
is not there, or pretend to be something else, is characteristic of children in the preoperational stage ( $2-7$ years). When children reach the concrete operational stage ( 7 - 12 years) they play games involving rules such as board games, sports or playground games (Fleer, 2013; Podmore \& Luff, 2012).

Piaget believed that children learned from actions, not observations (Smith et al., 2011), and “...constructed their own knowledge and meanings through their activities and explorations of their environment" (Podmore \& Luff, 2012, p. 19). In play children would act out already established behaviours or schemas (sets of linked mental representations of the world) and would adapt reality to fit these through processes he referred to as assimilation, accommodation, and equilibration (Smith et al., 2011). Piaget felt that play had two purposes. It could reinforce skills that a child already had through repetition of known schemas and it could give a child "...confidence and a sense of mastery" (p. 248). Although some of his research methods, and the universality of his stage-based ideas have been questioned, many of Piaget's ideas formed the foundation for future research in the area of play and child development (Brock, 2014). The influence of these ideas on the structures and approaches used in schools continues today.

Another theorist whose ideas on child development and play have had a widespread and ongoing influence in education, particularly in early years education, is Lev Vygotsky (1896-1934). Piaget's theories of child development and play emphasised the importance of play as a universal biological urge with the type of play children engaged in reflecting their developmental stage (Brock, 2014). Vygotsky, however, placed more emphasis on the social and cultural contexts of play 
(Brock, 2014), and he believed that learning and development were interrelated (Vygotsky, 1978). Vygotsky argued that “...play is not the predominant feature of childhood but it is a leading factor in development" (p. 101). He believed, like Freud, that the drive to play comes from "...the point when the child begins to experience unrealisable tendencies" (p. 93) which leads to the child entering a world of imagination where those desires can be realised. Vygotsky believed that play signalled the beginning of the development of the imagination (Fein \& Rivkin, 1986) which he saw as "..a specifically human form of conscious activity" (Vygotsky, 2016, p. 7). Play, according to Vygotsky, creates thoughts rather than reflecting them (Fein \& Rivkin, 1986).

Vygotsky (1978) disagreed with those who believed that learning should be matched to a child's developmental level and expounded the idea of a zone of proximal development. (ZPD) He believed that a child could perform above his or her actual developmental level through the assistance of an adult or capable peer. The ZPD is the distance between what a child could do independently and what they could potentially achieve with the appropriate level of support. He argued that play created the ZPD because

in play a child always behaves beyond his average age, above his daily behaviour; in play it is as though he were a head taller than himself. As in the focus of a magnifying glass, play contains all developmental tendencies in a condensed form and is itself a major form of development (p. 102).

Activities carried out within the ZPD, however, need to be meaningful and accessible to the child, they need to be "...sociocultural activities that the child can and wants to imitate" (Van Oers \& Duijkers, 2013 , p. 513). As well as providing opportunities for engagement in 
shared sociocultural activities, Vygotsky also believed play provided opportunities for social interaction between players of varying experience and knowledge, and for the development of the use of language and other symbols (Brock, 2014). When playing, children often use one object to represent another, for example a box can become a car, or a stick can become a sword. This separation of the object from its meaning is important to the development of abstract thinking (Brewer, 2007; Smith et al., 2011). Play also helps in the development of self-regulation. Vygotsky notes that when a child is playing and taking on a role, they have to act against their impulses in order to behave in the way the role dictates. A great deal of self-control is required to maintain this role and stay in character (Vygotsky, 1978).

Sutton-Smith (1924-2015) took a more critical view of the role of play in child development. After reviewing a range of studies on play (Sutton-Smith, 1997) he found that, while there was good cause to believe that play was positively associated with learning and development, he was sceptical that improvements in developmental outcomes were purely the result of play, and that an "idealisation" of play had begun to take hold in some quarters (Smith et al., 2011). He proposed that increases in children's scores after teachers had undertaken play training may have been as a result of the changed relationship between child and teacher rather than the play itself (1997).

Sutton-Smith contended that children do not see play as growth or progress. For them play is about being with friends, being outside, having fun, pretending and playing games. He argued that play was ambiguous, perhaps deliberately so, and that there may be no more motivation to play other than for the pure joy of playing and being alive 
in play. "Being at play is generally being more alive than usual in the world in which we all live" (Sutton-Smith in Nathan \& Pellegrini, 2011, p. 8). In his opinion, the extreme diversity and complexity of the meanings of play came about because of the diverse scholarly ways of viewing play, whether they were biological, sociological or psychological. While questioning the importance that had been placed on growth and development through play, Sutton-Smith (1997). held that play was likely to have a role in evolutionary adaptation, and that like many psychological characteristics, there is great variation between individuals.

Two other figures whose ideas have influenced the role of play in early childhood are Friedrich Froebel (1782-1852) and Maria Montessori (1870-1952). Froebel was concerned about the overly restrictive views on childhood that the influential Lutheran Church orthodoxy held in his native Prussia. In response he developed the kindergarten, or child's garden, a place outside the home where children between the ages of three and six years of age could be nurtured and allowed to develop through play, under the guidance of adults. His child-centred approach emphasised self-activity and he developed "gifts", such as blocks and shapes, and "occupations", such as weaving and sewing, that aligned with defined stages of development (May, 2005). Like Froebel, Maria Montessori valued children taking part in self-initiated activities under the guidance of adults. Montessori believed that multisensory experiences should precede the development of intellect. She designed a range of self-correcting formal apparatus that children could use independently. She did not, however, value sociodramatic or pretend play, preferring children to take part in actual household tasks rather than playing at them (Brock, 2014; May, 2011; Smith et al., 2011). 
Although there are disparate definitions and beliefs about the purpose of play, there is a general consensus among theorists that play has an important role in child development. Piaget and Vygotsky, who have, in different ways, focussed attention on how children construct their knowledge of the world, have had a particularly strong influence on play-based school curricula and the approaches that teachers take in their classrooms.

\section{Play-based learning}

Teachers and schools often use the term "play-based learning" to describe the way they are using play in their classrooms. An issue highlighted in the research about implementing play in classrooms is the different understandings teachers have of what play-based learning means (Baker, 2014; Fesseha \& Pyle, 2016; Hunkin, 2014; Martlew, Stephen, \& Ellis, 2011; Miller \& Almon, 2009). As a way to better understand these different perceptions of play a number of researchers have developed continuums to describe different classroom types (Brewer, 2007; Edwards, 2017; Miller \& Almon, 2009; Pyle, Poliszczuk \& Danniels, 2018; Weisberg, Hirsh-Pasek \& Golinkoff, 2013; Zosh et al., 2017). Common to all these continuums is the grouping of classroom types into three broad categories. At one end of the continuum are adult-led, highly structured classrooms where direct instruction is used. At the other end are loosely structured, free-play classrooms which are entirely child-led with little or no adult interaction. In between these two lies guided play, or play-based learning, which includes both childinitiated play, where adults observe and act as mentors, and teacherguided play, where teachers guide the learning by providing openended “...rich, experiential activities...” (Brewer, 2007, p. 142) that may link to specific concepts or learning goals. These activities may include 
adult-designed or scaffolded games (Zosh et al., 2017). This guided approach to play in the classroom is the focus of this research as the literature from New Zealand around using play as a pedagogy indicates that this is the method that most teachers are using.

\section{International trends}

To augment the scant research available about the experiences of primary school teachers introducing play into their classrooms, this paper draws on the adjacent body of literature which explores the shift towards using play in early childhood settings. Although New Zealand has long featured play in its early childhood education programmes, Gray and Ryan (2016) note that in the last 10 years there has been an increase in the number of countries moving away from traditional teacher-led models in the early years to those with a more play-based approach. They list Australia, Canada, Estonia, Poland, Sweden, and the United Kingdom as places where an emphasis on play-based pedagogies has been included in recent curricula. Iceland (Gunnarsdottir, 2014) also has a curriculum which highlights the use of play-based learning. In Asia, countries such as Malaysia (Puteh \& Ali, 2013), mainland China (Guo, 2013), and Hong Kong (Wu, 2015) are moving away from didactic practices and towards child-centred approaches to learning in their early childhood curricula.

\section{Kindergarten and pre-school findings}

In research with kindergarten and preschool teachers who had implemented play based curricula in Abu Dhabi (Baker, 2014), Malaysia (Puteh \& Ali, 2013), and India (Hegde \& Cassidy, 2009), there was unanimity in their belief that play-based learning and child-centred practices were more appropriate for their students' learning and 
development. Researchers found that none of the teachers involved with these studies felt that they had enough time to implement playbased learning in the way they would have liked. Training in the use of spaces and materials in a play-based environment was insufficient and in some cases the teachers did not feel they had adequate equipment or resources. These practitioners reported that there was a lack of support from their parent community towards using more play in the classrooms. and some teachers found they had to "...continuously hold workshops for parents [to] explain [it] to them" (Hegde \& Cassidy, 2009, p. 374). The teachers also found lack of support from administrators or management to be a barrier.

In all three studies teachers commented on the pressures they felt to include academic content in their programmes. These expectations led to a tension between the teachers' desire to offer more play-based learning and the need to instruct students in a more didactic way to ensure they had attained certain academic skills by the time they headed to the next grade level. This mismatch was also highlighted in Pui-Wah's study of a small group of kindergarten teachers in Hong Kong (Pui-wah, 2008; Pui-Wah \& Stimpson, 2004). She discovered that while all the teachers stated that they included play in their programmes, observations revealed that almost all used structured, academicallyfocused approaches, with play as “...a reward or a time for the children to relax after their 'work'” (Pui-Wah \& Stimpson, 2004, p. 343). The teachers seemed unaware of the opportunities they had to embed learning into the play. Similarly, in Norway, when interactions between adults and children were examined in four different kindergartens (Karlsen \& Lekhal, 2019), the researchers found that during free play periods, teachers spent very little time in supportive interactions with students, which meant that “...children may miss out on scaffolded 
learning opportunities and the ability to move beyond their current capabilities" (p. 10).

In 2010 in Ontario, Canada, the government released a new curriculum document which emphasised the use of play-based pedagogies in newly mandated full day kindergarten classrooms for three to five-year old students. Pyle and her colleagues conducted a number of studies exploring the perspectives and experiences of kindergarten teachers following these changes (Fesseha \& Pyle, 2016; Pyle \& Bigelow, 2015; Pyle \& Danniels, 2017; Pyle et al., 2018). These studies noted two distinct interpretations of play-based learning which had evolved from the teachers' understandings of the purpose of play and their role in a play-based classroom. One group of teachers saw play as a separate construct to learning. Play was a tool for social and personal development, and the teacher's role in play was as an observer, allowing students to develop their social skills independently. The teaching of academic skills was achieved separately through teacher-directed instruction. The other group of teachers believed that academic and social skills could develop concurrently through play. Their role was to observe, and to look for opportunities to extend learning through answering questions, offering resources or asking provocative questions (Pyle \& Danniels, 2017). Play was seen as a valuable learning activity where students and teachers co-constructed the activities or goals. Teachers provided the academic input through the play contexts.

Regardless of which approach teachers were using in their classrooms, they experienced similar issues when adopting a playbased pedagogy. Unsurprisingly, these challenges mirrored those faced by pre-school teachers in other parts of the world. In Fesseha and Pyle's 
(2016) survey of 69 teachers, the four most common challenges were parallel to those experienced by teachers in Abu Dhabi, India, and Malaysia. "Many participants expressed having difficulty finding the time they thought was necessary to plan concrete learning opportunities in a play-based context" (Fesseha \& Pyle, 2016, p. 370). Nor did the participants feel there was enough opportunity for openended play during the day when there were such high curricular expectations. Teachers, however, were still expected to continue to uphold the same high academic expectations prescribed in the previous curriculum (Fesseha \& Pyle, 2016).

The pressure to meet the academic demands of the curriculum was another major challenge for teachers. Like their colleagues in Asia and the Middle East, these teachers constantly sought to find a balance between having their students achieve prescribed academic levels and offering opportunities for play. Ontario teachers similarly experienced a lack of understanding from parents, administrators and colleagues and insufficient funding for appropriate materials in their classrooms (Fesseha \& Pyle, 2016).

A theme that was apparent across all nine studies in the different countries was the confusion that teachers had about their role when working in a play-based environment. While the teachers all held strong positive beliefs about play and its place in children's development, there was considerable uncertainty about what this should look like in the classroom. Teachers found it particularly difficult to find ways to embed academic learning into play, and to help students achieve academic goals when this type of learning did not emerge naturally from children's play. 


\section{Primary school findings}

Primary teachers in Ireland, Canada, Scotland, Finland, and Australia faced similar barriers to pre-school teachers in implementing play-based programmes - lack of time, lack of resources, inadequate funding of resources, and a lack of support from administrators (Gray \& Ryan, 2016; Jay \& Knaus, 2018; Martlew et al., 2011; Nolan \& Paatsch, 2018). The tension between providing a play-based programme and ensuring their students achieved expected academic standards was also a pressure for primary teachers. In two countries this was compounded further by teachers having to follow two conflicting curricula. In Ireland Aistear, a curriculum framework for children from birth to six years, overlaps with the Primary School Curriculum (PSC), which covers children from ages four to six. Aistear emphasises the centrality of play - "early childhood [is viewed] as a time of being not becoming" [emphasis added] (Gray \& Ryan, 2016, p. 190) with the teacher having a reciprocal role, while the PSC has more of a focus on academic attainment with the teacher seen as an instructor. Similarly, early years primary teachers in Western Australia are expected to operate under two curricula, one of which puts play at the centre of pedagogical practice while the other cites "...play [as] one of several strategies to meet achievement targets..." (Jay \& Knaus, 2018, p. 113).

Teachers in Canada and other parts of Australia, where play-based learning has become part of the early years' curriculum, also felt pressure for their students to achieve academically. Standardised testing is used to assess students at various points during their time at primary school and the teachers did not want to penalise their students by not preparing them for these assessments (Fesseha \& Pyle, 2016; Jay \& Knaus, 2018). 
Primary teachers in all these studies expressed enthusiasm and were positive about wanting to use more play in their programmes. They thought play was valuable and appropriate for young students' learning and development. However, the shift in mindset and the understanding of their role in a play-based classroom was a huge challenge (Gray \& Ryan, 2016; Hyvonen, 2011; Jachyra \& Fusco, 2016; Jay \& Knaus, 2018; Martlew et al., 2011; Nolan \& Paatsch, 2018). In some studies teachers experienced difficulty relinquishing control of the classroom when implementing child-centred, play-based learning, with one commenting that it was easier to control the students when they were sitting down at desks (Gray \& Ryan, 2016; Jay \& Knaus, 2018; Nolan \& Paatsch, 2018). Giving students free choice in their play was also difficult for many of these teachers. Despite their stated beliefs, they were often observed directing students towards specific activities rather than allowing them to choose or instructing students to carry out a task in a particular way despite it having been set up as an openended exploratory activity (Martlew et al., 2011; Nolan \& Paatsch, 2018).

Researchers also found that teachers struggled to understand how learning could happen through play, and were unaware of the possibilities of provoking or extending the play through their involvement. Play and learning were seen as separate entities with play used as a settling activity at the start of the day or while the teacher carried out administrative tasks or set up for the next session. Teachers felt that play was valuable for the development of the child as a whole and for helping students learn social skills but they did not see any value in play for the development of literacy, numeracy or other academic skills which they felt needed to be taught separately and in more traditional ways (Gray \& Ryan, 2016; Nolan \& Paatsch, 2018). In 
these classrooms, children often did have choice and played freely. However, these sessions were often short in duration and the teacher had little or no interaction with the students.

Primary teachers in these countries were expected to provide concrete evidence of learning, and formally report on this progress to management and parents. In a number of studies, teachers reported that they struggled with finding tangible ways to assess and show progress in a play-based classroom. They were aware that the use of observations, narratives or learning stories, and photographs were the best ways to capture this information but use of these methods came with further challenges such as finding the time, the cost of printing out photographs, and uncertainty about the rigour of these types of assessments (Gray \& Ryan, 2016; Jay \& Knaus, 2018; Martlew et al., 2011; Nolan \& Paatsch, 2018).

Some of the challenges that primary school teachers faced differed to those experienced by early childhood educators. Teacher:pupil ratios are not as generous at primary school which means that primary teachers are unable to be as responsive to children's needs or to monitor their learning as their pre-school colleagues (Martlew et al., 2011). Primary school “...classrooms as learning environments are not designed for activities other than sitting still..." (Hyvonen, 2011, p. 57) which means that teachers often struggle to adapt their spaces so students can move independently and freely in their play. Some teachers also expressed concern that play-based learning was just another government initiative being imposed on teachers and could fall by the wayside if not implemented well (Jachyra \& Fusco, 2016).

Another concern raised by primary teachers was a perception, often held by colleagues, that teaching in a play-based classroom was 
easier and did not require the skills that traditional teaching demanded. Teachers felt that by using play in the classroom their professionalism was being deskilled. This feeling came about because of lack of training, lack of experience, and lack of confirmation that they were implementing play-based learning correctly (Jay \& Knaus, 2018; Nolan \& Paatsch, 2018).

It is evident, therefore, that both early childhood and primary school teachers have comparable experiences and are presented with similar challenges as they introduce more play into their classrooms. Though policy makers have developed curricula that encourage or emphasise play-based learning, there has been a reluctance to let go of structures and assessments that would enable teachers to more fully embrace this style of teaching. A lack of professional development, particularly around their role in a play-based classroom and the ways that play and learning can be integrated, also inhibits teachers. Coupled with inadequate resources and spaces, it is no wonder then that while teachers stated that they believed in a play-based pedagogy, they were observed continuing to use mainly didactic methods in their classrooms, with play on the periphery (Gray \& Ryan, 2016; Jay \& Knaus, 2018; Martlew et al., 2011; Nolan \& Paatsch, 2018).

\section{The New Zealand context}

This section starts with a brief overview of the history and development of early years schooling in New Zealand. It includes some of the ideas about learning and child development that influenced policy makers and educators and is intended to provide some background within which to position beliefs about learning through play and its implementation in kindergartens, and junior school classes in New Zealand. It is not intended as a comprehensive historical 
overview of early years teaching and learning. The second part of this section explores recent trends in New Zealand with regards to playbased learning. It concludes with the research questions that informed this study.

\section{Historical overview}

In New Zealand, in 1877, the compulsory school starting age was set at seven years, although children could start school at five. This was reduced to six years in 1964, although it became the norm for children to begin school on their fifth birthday (May, 2005). In 2017 the Education (Update) Amendment Act made changes to the existing law to allow schools, and their communities, the choice between continuous and cohort entry for students starting school. The term "infants" was used until the 1970s to describe children up until the age of seven or eight years old.

The first schools were set up by missionaries in the 1830s and were based on ideas from England. Records suggest that the focus was on moral and religious training as well as the 3Rs (May, 2005). As Europeans started settling in New Zealand, a variety of different types of schooling for all ages emerged. Infant schools were appearing at this time, an indication perhaps that the teaching of younger students was seen as different from that of older students. As settler numbers increased and provinces were established in the 1850s, there was a boom in public school construction, and a continued diversity of school type including small private schools and home-based schools. Lecturestyle seating, known as infant galleries, were being built in some schools which allowed teachers to teach large groups of students at once, including infants. In one-room schools, a single teacher taught students of all ages, however in some towns or larger settlements infant 
schools or separate infant, preparatory, or junior classes for children under eight years of age were constructed (May, 2005). The focus of much teaching appears to have been on the 3Rs, the arts, discipline and orderliness. Object lessons, based on "...the sensory and verbal understanding of real objects" (p. 98) were taught by some teachers. There is a small indication that some inspectors considered the teaching of infants to be of importance for later performance, but this was by no means universal (May, 2005).

It was not until the 1870s that schools became more standardised. The Education Act of 1877 established a national curriculum and free compulsory schooling for European children aged seven to thirteen (May, 2005). There were six standards, each with an examination in reading, writing, spelling and arithmetic, which determined promotion to the next standard. The two primer years (for five and six year olds) were seen as preparation for passing the examination at the end of Standard One. There was some debate in the late 1880s about the presence of five and six year olds in schools. Those in favour felt that the early start to school had later benefits, while those against believed that school was detrimental, and children of this age should not be shut up in classrooms. Despite consideration of raising the admission age of students to six or seven, the policy of five year olds being allowed at schools remained. There was also unresolved tension between providing an interesting curriculum for infants and the need to learn enough to pass standardised exams (May, 2005).

The first documented kindergarten opened in Dunedin in 1889 (May, 1997). Kindergartens in the late nineteenth century were philanthropic and set up with the intent of supporting the lessfortunate and helping them to become good citizens (Sherley, 2011). 
They were established outside of the public school system, and have remained there ever since. In New Zealand, kindergartens adopted a version of Froebel's idea of the "child's garden" and his ideal of selfactivity which was firmly based on a philosophy of play (May, 1997). Some of these ideas began to make their way into schools and by the mid-1890s guidelines for teaching infants show a shift in thinking away from seeing this time as preparation for examinations and towards children's spontaneous play and the development of their senses (May, 2005).

In the early twentieth century a spate of initiatives indicated that changes in beliefs about the teaching of infants had started to make their way to New Zealand from the northern hemisphere. The 1904 primary school syllabus, with a focus on practical work and first-hand observation, reflects the influence of Dewey's ideas of "learning by doing" through play and activity (May, 2011). The classroom practices of some teachers were also influenced by the work of Maria Montessori, who emphasised the importance of educating the senses, and Susan Isaacs, who felt that childhood self-expression was the foundation for psychological well-being (Sherley, 2011). In the 1920s, some schools built open-air classrooms, allowing for more freedom in the way infant classes were taught, and in 1929 a revised syllabus for primary schools suggested teachers of Primers 1 and 2 avoid formal instruction and use stories and play in their teaching. In spite of these ideas, New Zealand teachers continued to mostly use traditional rote-learning styles of teaching during the first part of the twentieth century. This style of teaching continued after the Second World War when overcrowded classrooms often forced teachers to focus on management and order rather than new educational methods (May, 2011). 
C. E. Beeby, Director of Education in New Zealand from 1940 to 1960, had a vision for the New Zealand education system. He stated that every child should be provided with a free education that developed them to their fullest potential. This was the guide for education reforms in the middle of the twentieth century (May, 2011). Ideas about the educational value of play had been emerging from a range of theorists including Jean Piaget, who emphasised the importance of learning and understanding through experience, and Sigmund Freud who promoted self-expression and creativity. One of these reforms was the introduction of more play into the early years of school. In what was termed the "play way", teachers were to find opportunities to extend learning through comments and suggestions while children played, not be passive onlookers. The term "play way" became associated with Beeby, and he and his appointed advisors sought to relax the way things were done in both infant schools and kindergartens and "...learning through play became a mainstream method in the infant classroom" (pp. 124-125). Advice to teachers at the time recommended an hour of free play at the start of each day and stressed its developmental value. The term "developmental" was thereafter used by New Zealand teachers to label this period of time (May, 2011). Ideas about readiness for learning were also beginning to emerge at this time, and schools were encouraged to postpone formal teaching of literacy and numeracy until students were ready, focusing instead on pre-reading or prenumber training. Infant classrooms started to see their purpose as "providing an environment that enhanced 'readiness'” (Middleton \& May, 1997, p. 140).

Play-based learning continued to be a feature of infant classrooms in the 1960s and 1970s. In its 1962 report, the Currie Commission on Education was positive about the benefits of learning through play but 
noted that teachers, both young and old, were often ill-equipped to teach in play-based environments (May, 2011). Centres of interest or learning centres were also introduced in some classes in the 1960s. In these environments, students could choose from a range of teacherselected activities based around themes such as "insects" or "castles" (p. 196). In the 1970s many primary schools continued offering "Developmental Time" (Davis, 2018) but by the 1980s, this had sometimes become "choosing time" which was available when all the day's work had been done (May, 2011).

An increased focus on more academic learning and the subsequent erosion of play-based learning approaches in the early primary years began in earnest in New Zealand when new curriculum documents emerged in the late 1980s and early 1990s (Davis, 2018; Sherley, 2011). The 1993 New Zealand Curriculum Framework (NZCF) set out seven learning areas, made up of eight learning levels containing achievement objectives and learning outcomes for year one to 13 students. Included in this curriculum were a set of "essential skills" that were seen as "...the skills all people need...to operate across all life contexts..." (Brewerton, 2004, p. 4). Accountability and a return to the basics were a big focus of the new curriculum, and junior class teachers struggled to maintain play-based environments as they felt pressured to cover the curriculum while regularly gathering assessment data on students. The unique position and specialised teaching of infants was being lost as advisory services were cut, junior departments were integrated into the school, and school-wide planning became more commonplace. Rather than looking to early childhood practices for their pedagogy, junior teachers were now looking ahead to the next level of the curriculum for ideas about how and what to teach their young students (May, 2011). 
Shortly after the release of the draft NZCF, members of the early childhood community wanted to safeguard against an outcomes-based curriculum being introduced into their sector. A project team of early childhood educators and members of the Māori community was established (Mutch, 2004). A national curriculum for early childhood education, Te Whāriki, was written and launched in 1996 (May, 2001). This internationally recognised bicultural curriculum, which was updated in 2017, has play-based learning at its heart.

Children experience an environment where: heir play is valued as meaningful learning and the importance of spontaneous play is recognised (Ministry of Education, 1996, p. 82).

Children learn through play: by doing, asking questions, interacting with others, devising theories about how things work and then trying them out and by making purposeful use of resources (Ministry of Education, 2017, p. 46).

A section at the back of the earlier version of Te Whäriki (Ministry of Education, 1996) provided specific examples of how each of its strands linked to the eight essential skills, and seven essential learning areas of the $N Z C F$.

Interest in the transition from early childhood to school grew in the 1990s and early 2000s. A School Entry Assessment (SEA) tool with standardised tasks was made available to schools. Margaret Carr (1998) began developing Learning Stories, an assessment format designed to capture children's learning dispositions, and designed to ease the transition to school by providing teachers with information about the child as a learner. Other research explored ways in which students could be supported and scaffolded through the transition process by considering the theories of Vygotsky and the implications of his concept of the zone of proximal development (May, 2011). 
After a comprehensive review, a refreshed New Zealand Curriculum (NZC) was introduced in 2007 (Ministry of Education, 2007). One of the major changes that resulted from this review was the introduction of five "key competencies", defined as "...capabilities needed to undertake a task or meet a demand..." (Brewerton, 2004, p. 3). A link between the revised curriculum and the early childhood curriculum was more evident as the five strands of Te Whāriki were positioned next to the five key competencies, allowing for more continuity between early childhood and primary school (Carr, 2006). Specific reference to how transitions to school could be supported were also included in this document. In general, schools and teachers embraced the new curriculum with its broadly defined areas for teaching and learning, flexibility to develop a locally-based curriculum, positioning of assessment as part of the teaching as inquiry process, and a focus on competencies. There was some uncertainty for teachers, however, about how to incorporate the key competencies into teaching practices (May, 2011).

Just as teachers were beginning to adapt to the new curriculum, there was a change of government. That government introduced National Standards in 2010, with the intended aim of increasing student achievement levels. The standards benchmarked expected levels of achievement in reading, writing, and numeracy for students from years one to eight. In her report, Bonne (2016) notes that one of the impacts of National Standards, as reported by teachers, was that it had effectively narrowed the curriculum that they taught. Principals also indicated that their schools had moved away from giving attention to aspects of the curriculum other than literacy and numeracy. Some teachers also reported that anxiety about performance on National Standards had negatively affected student learning (Bonne, 2016). By 
narrowing the curriculum, and focusing their attention on accelerating students in numeracy and literacy, teachers were diverted from teaching the whole student (Bonne, 2016; Robertson, 2018). National Standards were a major focus for schools for the next eight years until, at the end of 2017, the newly-elected government fulfilled its election promise and removed them, stating that

Schools and parents have lost confidence in National Standards. They were too narrow, neither national nor standard, and did not...lift the bar (Hipkins, 2017, para. 4).

Early childhood educators saw the removal of the National Standards as an opportunity to encourage schools to take Te Whāriki into the junior school. During the eight years National Standards were in place there had been a push to increase academic content in the early childhood sector (May, 2018).

In spite of the move away from more holistic approaches to teaching and the narrow focus on literacy and numeracy during the National Standards era, some junior school programmes had managed to include "...periods of play, discovery and creative activities" (May, 2011, p. 284). One programme that was popular among teachers was Discovery Time which was developed by two educators who had noticed the new entrants in their school having difficulty transitioning to an academically-focused, teacher-directed programme (Fisher \& Martin, 2006; May, 2011). Built on the concept of "developmental", the programme involved the teacher planning a range of structured activity based experiences linked to student needs, curriculum learning areas, or essential skills such as sharing or persevering. A key component of the programme, and something that set it apart from "developmental", was the inclusion of time at the end of a session for sharing and reflection (Fisher \& Martin, 2006). 


\section{Recent trends}

In the same year that saw the demise of National Standards, a special edition of Set: Research Information for Teachers (Bolstad \& Roberts, 2018)entitled Learning through Play and Games, included a number of articles about play-based learning in the early years of primary school. Several of these were about the experiences of teachers and students in schools where play-based learning had been introduced (Blucher, Aspden \& Jackson, 2018; Buchanan, Donaldson, Stewart \& Davis, 2018; Davis, 2018; Hiini, MacKinnon, Lonergan, Spalding \& Bridson, 2018; Milne \& McLaughlin, 2018). An earlier article, published by CORE Education, also explored the journey of new entrant teachers and their students as they transformed their junior classrooms into play-based environments (Davis, 2015).

Teachers in these studies were motivated to introduce play-based learning by a desire to increase student engagement, to smooth transitions for students entering schools, and to shift teaching and learning away from industrial era practices. In research exploring different perspectives of a play-based learning approach in a new entrant classroom, Blucher, Aspden and Jackson (2018) found that the children, parents, teachers, and school leaders they interviewed all agreed that a play-based learning approach was more appropriate to student learning and development, promoted wellbeing, supported the social and emotional development of the students, and had a positive association with learning. Findings from Davis' (2015) research into a school's move to play-based learning for their new entrant and year one classes indicated that students were more engaged, teachers had fewer behaviour issues to deal with, students seemed more competent, both 
academically and socially, and were more creative and confident. The overall impact was students who

...were experiencing a broader, more balanced curriculum than they would have in a traditional new entrant/year 1 programme, as well as an altogether more motivating experience of school (Davis, 2015, pp. 11-12).

Teachers involved in Waiouru School's Teacher-Led Innovation Fund (TLIF) project also noticed increased engagement from students, particularly when they were the ones generating ideas for class activities (Buchanan et al., 2018). The new entrant teacher found students were more socially competent, had a keen interest in learning and were more willing to take risks. Although academic progress was slower than it had been previously, leaps were often made as students approached their seventh birthday (Buchanan et al., 2018; Davis, 2018). Teachers from schools who were developing play-based learning in the early years in a Western Bay of Plenty support network, found not only an increase in student engagement, and more positive interactions among students but a corresponding decrease in both student stress levels and the number of recorded behavioural incidents (Hiini et al., 2018). One school in the cluster found that “...their children still met National Standards requirements by the end of Year 4, but were more settled, exhibited fewer behavioural issues and gained success in relation to the key competencies" (Hiini et al., 2018, p. 72).

Teachers discovered that the changes they had made to their learning environments meant that transitions from ECE to school went more smoothly because "...the school [was] ready for the children...” (Buchanan et al., 2018, p. 14). It was the familiarity with the activities and the environment that made the transition to school easier (Blucher et al., 2018; Hiini et al., 2018). Play-based learning was seen as “...a 
valuable approach that enhanced the early learning experiences of children starting school" (Blucher et al., 2018, p. 57). Teachers at Waiouru School also

...noticed a definite difference in [the] new entrant children. They are confident, not only within their class environment, but in the school environment in general. Through play, children are able to show what they truly know and as a result teachers have raised their expectations (Buchanan et al., 2018, p. 44).

Teachers in these studies had to rethink their role in the classroom and their approaches to working with students (Davis, 2015). For the teacher, the understanding and use of both intentional and instructional teaching were factors in the success of the play-based approach (Blucher et al., 2018). Intentional teaching was the focus of Milne and McLaughlin's (2018) study which concluded that “...playbased learning requires the active, intentional, and planned actions of teachers to optimise child learning" (p. 49), and this is a skill teachers need to enrich play and extend learners.

Further evidence of a resurgence of interest in play-based learning appeared in online forums in 2018 and 2019. The Education Hub released a resource called " $A$ brief introduction to play-based learning" (2018) and in 2018 and 2019 Te Kete Ipurangi's New Zealand Curriculum Online section published several blogs. Titles included “Kaimai School - play based learning” (Robertson, 2018), “Learning through Play - what's it all about?" (Ministry of Education, 2019b), "Beginning a Journey into Play" (Allen, 2019a), and "Some misunderstandings about play" (Allen, 2019b). Two blogs covered the connection between the NZC and Te Whāriki (Ministry of Education, 2018a, 2018b). Education Central also posted two blogs in 2019 (Education Central, 2019a, 2019b). In one, the benefits of play-based 
learning are expounded while in the other Tara O'Neill describes her journey into play-based learning at Te Karaka School and Haeata Community Campus. In 2015 Tara established a Facebook group "Learning through Play", which has since grown to just over 11,000 members. There has also been growing interest from New Zealand schools in adopting the Walker Learning Approach (WLA), an Australian play and project-based programme. The WLA offers "an intentional teaching and learning approach for children in their early childhood and primary years" (Early Life Foundations \& The Walker Learning Group, n.d., para. 1) and focuses on engagement through the authentic interests of the students.

The growing quantity of literature about play-based learning in the early years of primary school in New Zealand is limited by the small sample sizes of the studies, and the unique situations studied. Given the acknowledged paucity of New Zealand research in this area, along with the mounting interest in play-based learning, this study will add to the body of knowledge around play-based learning in the early years of primary school in New Zealand. By investigating the journeys of teachers across a selection of schools and analysing their accounts as they transition to using play-based learning in their classrooms, this study will examine the impact of this transition, and implications for policymakers, school leaders, and early primary teachers.

\section{Research questions}

As this research is exploratory in nature, a qualitative approach will be taken. The four research questions that form the basis of this study are: 
1. What pathways have teachers taken in their transition to a playbased classroom?

2. What are the reasons teachers of students in years one to three are transitioning from traditional to play-based classrooms?

3. What changes in practice have teachers made as a result of this transition?

4. What changes in beliefs about themselves as teachers have occurred as a result of this transition? 


\section{Methodological approach}

This was a small-scale study conducted with five teachers across four schools in New Zealand. A qualitative methodological approach was taken, as this was an open-ended, exploratory study (Johnson \& Christensen, 2012). It examined teachers' perspectives on their experiences of changing their approach to teaching and learning. A sociocultural perspective to generating and analysing data was taken in the belief that learning is both a social and cultural activity. In a playbased environment, students use the tools of their culture and the input of adults and other children to learn (May, 2011; Van Oers \& Duijkers, 2013). Open-ended interviews and observations were used to gather data. The observations focused on the ways the classrooms were set up, and the tools and equipment visible in each environment. In addition, during the observations, only interactions between teachers and students were recorded. During the interviews, participants were asked about the ways they had established play in their classrooms and the materials they used in their environments. Participants were also asked about changes they had made to the ways they interacted with their students. A thematic analysis method was used to identify themes or patterns of meaning across the data (Braun \& Clarke, 2006).

\section{Methods}

\section{Participants}

A purposeful sample of five participants was recruited to take part in this research. I approached my existing networks of current and excolleagues to invite teachers of year one to three primary school students who were using play-based learning programmes. For convenience, to take part in the research schools were selected from the 
greater region of a metropolitan city. The participants were all teachers who had been teaching year one to three primary students for at least four years and were currently transitioning from using traditional approaches to using play-based learning approaches within their classrooms. Experienced teachers were chosen to allow for reflection on any changes they had made to their practice and to their beliefs about teaching and learning. Initial emails, including information sheets and consent forms, were sent to the principal and teachers at seven schools. Four of the seven schools agreed to participate, and five teachers were interviewed and observed.

\section{Profiles}

Three of the schools were in urban locations and one school was in a rural township. The schools were all located in higher socioeconomic status areas. Two schools were full primary (years one to eight) and the other two schools were contributing schools with students up to year six. The schools were all of medium size, with rolls that ranged from approximately 270 to just under 400 students.

All five teachers had been teaching for at least four years with three of the teachers each having over fifteen years' teaching experience. Most of the teachers had spent the majority of their time teaching junior students or saw themselves as junior teachers. All of the teachers were in classes with new entrant or year one students.

\section{Data collection}

\section{Interviews}

A semi-structured interview schedule (see Appendix A) was used as the basis for the interviews. To begin, an open question about the teacher's journey into play-based learning was asked. This was 
followed by questions about their motivation to make the transition, any changes they had made to their practice, and how the experience had changed their relationships with students, parents, and colleagues. The interviews each took approximately one hour, were audio-recorded and later transcribed. Three teachers were interviewed individually and two teachers, who co-teach, were interviewed together.

\section{Observations}

A qualitative, sociocultural approach to the observations was used. Rogoff (2003) provides a framework of three lenses through which to observe sociocultural activity. They are personal, interpersonal, and community or cultural/institutional. While all three lenses were used, the main focus of the observations was on the teachers' interactions with their students.

A narrative observation schedule (see Appendix B) was used as this placed more of an emphasis on relationships with people, places, and activities (Podmore \& Luff, 2012). The teacher's actions and interactions with students were manually recorded on the schedule during each of the 2 hour-long observations. Information about the environment was also gathered during these observations. This included making a sketch of the classroom space, a brief description of the classroom type (single cell or shared space), the set-up, and resources and equipment available. One observation was carried out prior to the interview, and the second observation occurred later.

The nature of the observations reflected the doubleness of the researcher (Fleer \& Veresov, 2018) where I was a non-participant observer (Podmore, 2006), being both a person in the research context who might interact with children if they approached me, but also a 
researcher with a clear role to play observing the teacher and recording their interactions with the students.

Participants were given the opportunity to review copies of their interview transcript and observation field notes, and amend them prior to analysis. None of the teachers requested amendments. Clarification of some details from the interviews was made during the second observation and through emails.

\section{Data analysis method}

A reflexive thematic analysis approach (Braun \& Clarke, 2006; Mutch, 2013) was used to analyse the data. The software package NVivo was used to organise the data and support the analysis process. The interviews were transcribed verbatim to ensure accuracy and trustworthiness. The six phases of thematic analysis, as suggested by Braun \& Clarke (2006), were used for this analysis and are described below in Table 1.

\begin{tabular}{|l|l|}
\hline Phase & Description of the process \\
\hline Familiarisation with the data & $\begin{array}{l}\text { Interviews and field notes from } \\
\text { observations were transcribed } \\
\text { solely by the researcher. } \\
\text { Interview transcripts were read } \\
\text { and re-read. } \\
\text { Nascent ideas for codes were } \\
\text { noted. }\end{array}$ \\
\hline Generation of initial codes & $\begin{array}{l}\text { Initial codes were developed in } \\
\text { an inductive and semantic way, } \\
\text { and linked to each of the four } \\
\text { research questions. } \\
\text { All the interview schedules were } \\
\text { coded. }\end{array}$ \\
\hline Searching for themes & $\begin{array}{l}\text { The initial codes were then } \\
\text { collated and examined to identify } \\
\text { broader patterns of meaning. }\end{array}$ \\
\hline
\end{tabular}




\begin{tabular}{|l|l|}
\hline Reviewing themes & $\begin{array}{l}\text { Themes were reviewed, checking } \\
\text { to see if they answered the } \\
\text { research questions. Themes were } \\
\text { refined through combining and } \\
\text { discarding. }\end{array}$ \\
\hline Defining and naming themes & $\begin{array}{l}\text { Themes were defined and named } \\
\text { as they became clearer. }\end{array}$ \\
\hline Writing up & $\begin{array}{l}\text { The themes were used to write a } \\
\text { narrative that answered the } \\
\text { research questions. } \\
\text { Field notes from observations } \\
\text { were used to supplement the } \\
\text { themes. }\end{array}$ \\
\hline
\end{tabular}

Table 1: Thematic analysis phases

\section{Ethical considerations}

Voluntary informed consent from teachers and school principals was obtained for the observations and the interviews. Parents and whānau of students being observed were informed of the purpose of the research and the nature of the observations. They had the opportunity to dissent to their child's interactions being recorded during the observations. No parents or whānau dissented. No schools are identified by name and pseudonyms for all participants are used to protect their anonymity. One of the teachers in this study is an excolleague. I had not met any of the other four teachers prior to them being participants in this research.

\section{Reliability and validity}

The reader of qualitative research needs to feel confident that the research has been carried out rigorously, and is "...plausible, credible, trustworthy, and therefore defensible" (Johnson, 2014, p. 299). Lincoln and Guba (1985) suggest four means by which trustworthiness can be established. These are credibility, transferability, dependability, and confirmability. 
This research includes several activities that contribute towards its credibility and dependability. Sufficient time has been spent in each setting building trust and rapport with the participants. An observation was made prior to, and following, each interview to gather contextual information, and to build relationships with the interviewees. Triangulation of data sources, through the use of both observations and interviews was utilised to increase internal validity (Johnson, 2014; Lincoln \& Guba, 1985). This study has been undertaken as part of a Masters programme, and has included on-going supervision and feedback through the research processes of Victoria University of Wellington. These have included peer reviewing of the research proposal, an ethics approval process, and continuing supervisor feedback and advice. Respondent validation can "...ensure that observations accurately depict what they are designed to show,...[are] meaningful and "ring true"..." (Podmore, 2006, p. 98). All interviews were transcribed verbatim, and participants were given the opportunity to review both the interview transcripts and observation field notes.

Lincoln and Guba (1985) recommend the use of thick descriptions to establish transferability. This study provides detailed information about the participants' settings and includes low-inference descriptors, in the form of verbatim quotes (Johnson, 2014), to ensure the perspectives of the participants are represented accurately.

The ability to be completely objective when carrying out observations has been considered by researchers (Malterud, 2001; Podmore, 2006). Malterud (2001) stated that "A researcher's background and position will affect what they choose to investigate, the angle of investigation, the methods judged most adequate for this 
purpose, the findings considered most appropriate, and the framing and communication of conclusions" (pp. 483-484). By practising reflexivity, and declaring their beliefs, researchers can account for bias, knowing that it cannot be totally eliminated (Lincoln \& Guba, 1985; Malterud, 2001). My own background is foregrounded in the introduction to this study. Literature that offers contrary views is included in the review section, and during the analysis stage, the data was read and re-read, and codes and themes were reviewed and revisited. These practices have contributed to the confirmability of this study. 


\section{Findings}

This section presents the findings from this study. It is structured around the four research questions used in the interviews.

Table 2 provides information on the participants, their classroom environments, and how and when play occurred.

\begin{tabular}{|c|c|c|c|c|}
\hline Teacher & Indoor space & $\begin{array}{l}\text { Outdoor } \\
\text { space }\end{array}$ & $\begin{array}{l}\text { Other } \\
\text { teachers }\end{array}$ & $\begin{array}{l}\text { Timing of } \\
\text { play }\end{array}$ \\
\hline Bonnie & $\begin{array}{l}\text { Single cell } \\
\text { classroom. } \\
\text { Access to } \\
\text { two other } \\
\text { single cell } \\
\text { classrooms. } \\
\text { Corridor } \\
\text { space and a } \\
\text { cloak bay } \\
\text { area } \\
\text { available. }\end{array}$ & $\begin{array}{l}\text { Fenced } \\
\text { outdoor area } \\
\text { immediately } \\
\text { outside } \\
\text { classroom, } \\
\text { includes } \\
\text { sandpit. }\end{array}$ & $\begin{array}{l}\text { Three } \\
\text { teachers } \\
\text { with some } \\
\text { team } \\
\text { teaching. }\end{array}$ & $\begin{array}{l}\text { Play } \\
\text { happens } \\
\text { nearly all } \\
\text { day. } \\
\text { Morning - } \\
\text { literacy and } \\
\text { guided } \\
\text { reading } \\
\text { groups; } \\
\text { middle } \\
\text { block - } \\
\text { numeracy; } \\
\text { afternoon } \\
\text { block - } \\
\text { inquiry. }\end{array}$ \\
\hline Hannah & $\begin{array}{l}\text { Modern } \\
\text { Learning } \\
\text { Environment } \\
\text { (MLE) - } \\
\text { three indoor } \\
\text { spaces. }\end{array}$ & $\begin{array}{l}\text { All outdoor } \\
\text { areas } \\
\text { accessible } \\
\text { from } \\
\text { classroom. }\end{array}$ & $\begin{array}{l}\text { Two } \\
\text { teachers } \\
\text { team } \\
\text { teaching. } \\
\text { Both } \\
\text { teaching and } \\
\text { roaming. }\end{array}$ & $\begin{array}{l}\text { Afternoon } \\
\text { session. } \\
\text { Teachers } \\
\text { take guided } \\
\text { reading } \\
\text { groups and } \\
\text { support the } \\
\text { play. }\end{array}$ \\
\hline Lucy & $\begin{array}{l}\text { MLE - two } \\
\text { classroom } \\
\text { spaces. } \\
\text { Cloakroom } \\
\text { and } \\
\text { withdrawal }\end{array}$ & $\begin{array}{l}\text { Limited } \\
\text { access to } \\
\text { outdoor } \\
\text { spaces due to } \\
\text { building } \\
\text { construction. } \\
\text { Access to a }\end{array}$ & $\begin{array}{l}\text { Two } \\
\text { teachers } \\
\text { team } \\
\text { teaching. } \\
\text { Initially one } \\
\text { teaching and } \\
\text { one roaming }\end{array}$ & $\begin{array}{l}\text { Morning } \\
\text { session. } \\
\text { Teachers } \\
\text { take guided } \\
\text { reading } \\
\text { groups and }\end{array}$ \\
\hline
\end{tabular}




\begin{tabular}{|c|c|c|c|c|}
\hline & $\begin{array}{l}\text { room } \\
\text { available. }\end{array}$ & $\begin{array}{l}\text { deck and } \\
\text { parts of the } \\
\text { playground is } \\
\text { anticipated. }\end{array}$ & $\begin{array}{l}\text { but both will } \\
\text { be teaching } \\
\text { and } \\
\text { supporting } \\
\text { play } \\
\text { together. }\end{array}$ & $\begin{array}{l}\text { support the } \\
\text { play. }\end{array}$ \\
\hline $\begin{array}{l}\text { Olive } \\
\text { and Pat }\end{array}$ & $\begin{array}{l}\text { MLE - two } \\
\text { classroom } \\
\text { spaces with } \\
\text { a range of } \\
\text { withdrawal } \\
\text { rooms set up } \\
\text { as specialist } \\
\text { areas. }\end{array}$ & $\begin{array}{l}\text { Access to all } \\
\text { parts of the } \\
\text { school } \\
\text { grounds. } \\
\text { Woodwork } \\
\text { table } \\
\text { available near } \\
\text { classroom. } \\
\text { Scooters } \\
\text { freely } \\
\text { accessible. }\end{array}$ & $\begin{array}{l}\text { Two } \\
\text { teachers } \\
\text { team } \\
\text { teaching. } \\
\text { Both } \\
\text { roaming } \\
\text { during play } \\
\text { with a small } \\
\text { amount of } \\
\text { individual } \\
\text { teaching. }\end{array}$ & $\begin{array}{l}\text { Monday to } \\
\text { Thursday: } \\
\text { Morning } \\
\text { block - play, } \\
\text { with both } \\
\text { teachers } \\
\text { roaming. } \\
\text { Middle } \\
\text { block - } \\
\text { phonics } \\
\text { with option } \\
\text { to play. } \\
\text { Afternoon } \\
\text { block - } \\
\text { numeracy, } \\
\text { PE, } \\
\text { emotional } \\
\text { self- } \\
\text { regulation } \\
\text { programme. }\end{array}$ \\
\hline
\end{tabular}

Table 2: Summary of participants and their classroom set ups

\section{Pathways into play}

Teachers drew on their own experiences and research to introduce play into their classrooms. All five teachers in this study initiated play-based learning programmes in their schools themselves, or in collaboration with another colleague. This was achieved either through teacher inquiry or by approaching their school leader and getting approval to start using play in their classroom. are going to ... job share [and] if we are going to open the 
new classroom, I'm not doing it another way but playbased". [Pat]

The move to play-based learning usually started out as a small change to the structure of the week or the day, and evolved from there. Typically, teachers began with one or two mornings or afternoons of play or Discovery Time per week, then gradually increased the amount of play they included in their programmes until it became part of their daily programme.

Two teachers had previous experience or knowledge of playbased learning environments in which their own, or other children they knew, had participated. Both of these teachers had seen benefits of play-based approaches. One teacher had been heavily involved in a play-based early childhood centre with her children. She felt that their language skills and confidence were stronger than their peers, particularly when interacting with adults, and she attributed these strengths to them having been in a play-based environment. The other teacher had taught at an international school, which her own children had attended, and which followed a play-based curriculum. She was also interested in Montessori and Steiner schools. She particularly liked the Steiner philosophy with its focus on creativity and the use of natural materials, and the fact that their students do not start formal learning until they are seven years old.

Teachers took an investigative approach to introducing play into their classrooms. They used a range of ways to find out about playbased learning including attending courses, visiting schools, reading and researching, and tapping into the expertise of colleagues. Nearly all the teachers in this study had participated in at least one course at Longworth Education, a consultancy group specialising in supporting 
schools and teachers to develop student-centred learning environments. The only teachers who had not attended any Longworth sessions had begun their journey into play prior to courses being available. Several teachers had also attended presentations by neuroscience educator, Nathan Wallis, on brain development, such as The Developing Brain and The Teen Brain (Wallis, 2019).

While none of the schools in this study have adopted the Walker Learning Approach as a prescribed programme, the teachers have all found aspects of this play-based method useful in guiding them on their journeys. One teacher attended a professional development course with the developer of the programme. She and her colleague also visited a school that uses the Walker Learning Approach school-wide.

Many of the teachers had used the Walker Learning Approach book, Play Matters (Walker, 2011), as a guide to setting up their classroom, but they had also read widely on brain development, child development and play-based learning. A further useful source of information and support was the Learning through Play Facebook page to which all the teachers in this study subscribed. Along with regular member posts, this page has an archive of documents, photographs, videos, and webinars available. Two founding members of the page, who have been using play-based learning approaches for some time, also provided more personal support and guidance to some of the teachers in this study.

Two of the schools have recently hired staff with early childhood expertise and the teachers in this study really appreciated being able to glean information from them about ways to implement play-based learning. They particularly found their advice on types of resources to use, ways to follow children's interests, how to ask provocative 
questions, and how to keep track of children's learning very useful. One teacher also worked briefly with a teacher who had come from a purely play-based environment and learned a lot about ways she could incorporate more play into her classroom. Teachers also visited schools and early childhood education centres to observe play-based learning in action and to seek advice.

We were learning as a team all about urges, we happened to have ... a teacher ... who was a Masters student with an ECE background. She was really kind of helpful in terms of giving us resources - and I did one of the Longworth courses and I read the Walker book. [Hannah]

Teachers received both support and resistance from colleagues and parents. School leaders had been cautiously supportive of teachers introducing play-based learning into their classrooms. All the teachers in this study had support from their senior leadership team to implement play-based learning. Senior leaders showed an interest in learning through play and gave permission - explicitly or tacitly - for the teachers to embark on their play-based learning journeys. In one school the leadership team were already aware of research that showed children were not getting enough time playing outside or in nature. In another school, the principal attended a professional development course with staff to increase her understanding of play-based learning. Several teachers, however, noted that while supportive, senior leaders were also somewhat cautious about the value of play to the students. They sought reassurance that students would continue to succeed academically in play-based environments, and that the teachers had processes in place to review and measure the success of their programmes. In one school some members of the leadership team worried that play-based learning was too experimental, and they continued to want students to achieve at National Standards levels in 
literacy and numeracy, even though the time spent explicitly teaching these learning areas had been reduced. The teachers valued the support that their leadership teams provided, but at times felt under pressure to prove that play-based learning was of equal, or better, value for the students than more conventional teaching approaches.

The teachers in this study had been team teaching, or collaboratively teaching throughout their play-based journey. They placed a high value on having another staff member with whom they could share ideas and plan collaboratively; someone who was " $100 \%$ on the same page" [Lucy] as them. In some schools the teachers found that play-based learning had begun to spread beyond their classroom and was finding purchase in other areas of the school. Sometimes this was due to a like-minded colleague moving to another year level. In other schools it was due to the philosophy of the school leader who hoped that teachers would be influenced by what they saw happening and come to play-based learning of their own volition. In some schools the teachers could see that play was happening in other parts of the school in the form of passion or inquiry based projects.

All the teachers also experienced "pushback" from colleagues about them introducing play-based learning into their year one classes. The greatest resistance came from colleagues who taught children in the year level or class above theirs. These teachers were concerned that the students who moved to their class after a year in a play-based environment would not have attained the literacy or numeracy levels they had come to expect. They were also worried that the students would not have the skills or knowledge of those who had been in a teacher-led classroom and would find it difficult to learn in a more structured classroom environment. The response of several teachers in 
this study, however, was that it was the responsibility of their colleagues to adjust their expectations, their teaching and the transitioning of students into their classrooms.

When we opened the first classroom, the questions were straight away "So how will they transition?" "How will they come to me next year and how will the kids be?" "How will they transition?" Well - [my response is] "What will YOU do to transition them? How will you change your programme?" [Pat]

Parents sometimes needed convincing of the value of play. Nearly all the teachers in this study had spent time explaining the merits of a play-based programme to their parents. In Hannah's school the parents seemed to accept that their children were in a play-based environment, however, she was aware that the parent community had high expectations about the amount of daily homework their children would get. She felt that students needed to go home with a daily reading book at the very least. She also found herself reiterating the school's position on maximum homework levels and the need for social activities after school. Bonnie, Lucy, Olive and Pat, however, have had to explain the reasons for moving to play-based learning to their parent community. They achieved this by holding meetings, sending researchbased information home, and putting up displays in their classrooms about the benefits of play, and the links between play and the curriculum. In Olive and Pat's school there was initial resistance towards play-based learning because parents felt that school was a place where children should be formally taught to read and write, not a place to be "...mucking around..." [Pat] and playing. They had a small number of parents remove their children from the school when they first started their play-based classroom. Now they find that parents are 
approaching them, and confirming they are still running a play-based programme because they have seen the benefits for their older children.

The parents have come around. I think they are seeing that their children are still learning to read and write... I think they've seen how happy their children are... [Olive]

\section{Reasons for transitioning to play-based learning}

The main motivator for teachers in this study to transition to playbased learning was their belief that the current methods of teaching were not appropriate for the learning and development of young students. As a result of their own research, particularly into brain development and neuroscience, several of the teachers in this study were questioning why they were teaching their students in formal ways before they were seven years old. Olive reflected on this after attending a presentation by Nathan Wallis.

... I'd listened to Nathan Wallis... and it really got me thinking... What are we doing with our little people? Why are we forcing them to learn before they-it's like running before they've learned to walk... [Olive]

Lucy and Pat also questioned the rationale behind teaching students before their brains were ready to cope with formal learning.

...especially with us knowing that seven is the magic number when the brain is actually ready for this formal learning. So, everything that we do for the first two years is just damaging them really. Forcing it. [Pat]

Most of the schools involved in this study followed an inquiry learning model where a theme, or topic that linked to one or more curriculum learning areas, was explored by the whole school for a term. After being introduced to the topic and exploring ideas around it, students would then be expected to follow a personal line of inquiry 
within the topic, culminating with a presentation of their findings or an action to take. The teachers in this study had begun to question the appropriateness of this model with their year one students and felt that exploring topics or themes in a play-based environment would be more suitable for their classes.

.... another part of the reason that we shifted [to play-based learning] is we have a whole school inquiry focus and sometimes ... we were just finding that it was really hard to pitch it to our children....If we actually planned it with play in mind... [and] we did a whole lot of hands-on experiences and we pulled out discussion groups... we found it was a lot easier to think and to kind of pitch it to our kids through the play and ... there was less mat time - and it was sort of a bit more easy for them to understand things. [Hannah]

Discussions were also happening in Bonnie's school about inquiry learning and its appropriateness for new entrant students.

... [we] had a big discussion at the end of 2017 - "Well, really, are our new entrants capable of doing a true inquiry?" when you are thinking about the whole process of inquiry. Definitely the tuning in and the finding out - all of that - but should we be assessing them on the true inquiry, or should we be starting to inquire through provocations and watching and going that way? [Bonnie]

In Olive and Pat's school there had been a school-wide move towards skill development. Pat explained this shift as she added to their reasons for moving to play-based learning.

Another thing that I think was because ... the move in our school was to focus on skills, skill development and that came hand in hand because what better way than playing you know. So that was, for us, a big motivation as well. [Pat]

At three of the schools in this study the teachers had also started noticing that students were arriving at school lacking social skills, and 
with poor oral language development. The teachers felt that a playbased environment would be a more appropriate place in which to develop both of these areas.

...the reason for going into play-based was pretty much responding to their needs, what we noticed in the kids. The ... social needs, the language needs. [Pat]

In Hannah's school there were increasing numbers of students arriving with English as an additional language as well as some students who had not attended an early childhood education centre. In addition, she had become aware of a growing number of students with high behavioural needs and felt that "suddenly the pendulum had swung and actually...it was taking kids a bit longer to develop a sense of belonging" [Hannah]. Lucy also noticed that more students were coming to her school with poor oral language, despite English being their first language. She noted

...some kids in the class [their] oral language is shocking...[they] can't even string a sentence together. They're from a dominant English-speaking home, but their language is terrible. [Lucy]

All the teachers believed that having a play-based new entrant classroom was one way that the transition from early childhood centres to school could be made smoother.

...I'm not sure they're getting everything they need at ECE and I'm not sure that our transition is as smooth as it could be and that's sort of how I started looking into that.

[Hannah]

It was with these new perspectives on traditional methods of teaching that the teachers in this study began to make changes to their practice. 


\section{Teachers have changed their practices}

\section{Adaptations to the teaching environment}

Teachers in this study have changed the way they organise their classroom environments. All the teachers allowed their students to move freely between two or more classrooms, and in most of the schools, students also had ready access to outdoor playground spaces where they could run, scooter, play in the sandpit or on a field, or use woodworking tools. The teachers had repurposed a number of spaces in and around their rooms to accommodate play. Withdrawal rooms, corridors, cloakrooms, and resource rooms had all been converted into areas for play. Many of the spaces set up in the classrooms reflected the areas suggested in the Walker Learning Approach's Play Matters book (Walker, 2011). Pat outlined them:

\section{Through their research - because everything in the book is research based - they recommend five areas. Dramatic play, collage, sensory, construction and there's always a reading corner and writing workshops. [Pat]}

Table 3 lists examples of observed play areas that align with the Walker Learning Approach's recommendations.

\begin{tabular}{|l|l|}
\hline Areas of play & Examples observed in classrooms \\
\hline Dramatic play & $\begin{array}{l}\text { Dress ups, doll's houses, kitchen areas, family } \\
\text { areas. } \\
\text { Specific shops such as a hairdresser, a vet clinic, } \\
\text { an ice cream shop, or a cafe. }\end{array}$ \\
\hline $\begin{array}{l}\text { Collage/creating } \\
\text { area }\end{array}$ & $\begin{array}{l}\text { 'Making' tables with paper, cardboard, tape, glue } \\
\text { guns, ice block sticks. } \\
\text { A large pile of different sized cardboard boxes. } \\
\text { Painting materials and easels. }\end{array}$ \\
\hline Sensory & $\begin{array}{l}\text { Playdough, sandpit, 'potions' table, large } \\
\text { container of leaves, sticks, and flowers. }\end{array}$ \\
\hline
\end{tabular}




\begin{tabular}{|l|l|}
\hline Construction & $\begin{array}{l}\text { Wooden blocks, Lego, Mobilo. } \\
\text { Sometimes these were set up in separate rooms. }\end{array}$ \\
\hline Reading corner & $\begin{array}{l}\text { Library corners with a wide range of books and } \\
\text { comfortable seating, e.g., sofas, chairs, cushions. }\end{array}$ \\
Writing \\
workshops & $\begin{array}{l}\text { Spaces set up with blank paper, worksheets, } \\
\text { chalkboards, whiteboards, and clipboards. } \\
\text { Writing materials such as pencils, pens, felt } \\
\text { tipped pens, whiteboard pens, and chalk. } \\
\text { Sight words displayed on the walls. }\end{array}$ \\
\hline
\end{tabular}

Table 3: Types of play areas observed

Other equipment and spaces that were set out in the observed classrooms included toy town mats and cars, small worlds, and science tables. All the classrooms had equipment or spaces related to numeracy including loose parts for counting, such as counters or teddies, measuring equipment, and geometric shapes and puzzles. One classroom had a tinkering room with old toasters and computer parts, tools and safety gear. While the Walker Learning Approach “...embraces the use of a range of technologies (including the use of computers) as...tools for learning..." (Walker, 2011, p. 49) none of the classrooms observed in this study had computers set up and available for students. In the two schools who were using elements of the Walker Learning Approach, iPads were used by selected students to take photos.

The teachers thought carefully about what they put out for children to play with, mindful that whatever was presented could change the nature of the play.

What you put out can completely change...how the play works - and you can put out pictures or words or whatever. [Lucy]

Some of the invitations to play were based on the current inquiry topic while others came from the students' interests. These are some 
observed ways that the teachers in this study had set up invitations to play:

- A large container with twigs, flowers and leaves available for students to create a habitat for a dinosaur at a school inquiring into animal habitats.

- In a classroom where geometry had been the focus of explicit mathematics teaching, a table of geometric puzzles and containers of shapes was set up.

- In a school, where the whole-school inquiry focus was on the local beach, several areas had been set up across three classroom spaces a "beach" (yellow cloth, swimming rings, and lifeguard uniforms), an ice-cream shop, a fishing area, and a takeaway shop.

- An outside "potions" table had been set up in response to students getting things down from the shelves and mixing them.

Despite their carefully planned invitations, teachers often found that students used the equipment in quite different ways to what was intended, however the teachers were learning to accept this.

We try to set up our environments and predict what could happen... and what we would like them to get out of it. Very often it could vary - you know, their own ideas - and [it] goes in a very different way that we wouldn't predict. But it's still OK. We let them go for it. [Pat]

...something that I'm continually becoming more and more aware of as we explore learning through play, and we learn more about our children is that you just have to run with things sometimes. It's nice to plan to do something but sometimes they just won't pick it up and they just won't engage with it and you've just got to make it something else or build on something else. So, it's a balance for us in terms of planning a couple of things and then totally doing our very best to notice what they're hooking into and then trying to extend that. [Bonnie] 
Adapting the way they set up their classroom environments had been a challenge for the teachers in this study as they embarked on their play-based journey. However, making changes to the way they taught proved to be equally, if not more, demanding.

\section{Adaptations to teaching programmes}

All the teachers commented that they were constantly adapting and changing the way they organised their programmes as they found out more about play-based learning, gained confidence in implementing it, or responded to their students' needs. They had all experimented with having play at different times of the day, and for differing lengths of time. Starting the day with play was one of the most common approaches, and Bonnie had adopted a "soft start" where students continued to play after the morning bell had gone, rather than meeting the teacher on the mat. After finding that students were tiring in the afternoon, Hannah moved her inquiry time to the morning session, when the students were fresher and more focused, and play was shifted to the afternoon. Olive, Pat, and Lucy all ran their play sessions in the morning so that students could "get that out of their system" [Lucy] and be focused for later more formal learning sessions.

A challenge for all the teachers was finding the time for formal learning, particularly the teaching of daily guided literacy groups, while still allowing for play. Some teachers experimented by alternating reading and writing each day or reducing the number of reading groups they met with daily. Olive and Pat ran a highly structured phonics programme in place of a more traditional approach to the teaching of reading. Students whose phonics knowledge had reached a certain level read individually with a teacher during the morning play session. Bonnie, Hannah and Lucy had students in groups based on their reading 
levels and met with these groups on a regular basis. However, the students were free to play when not reading with the teacher. Bonnie and Lucy both supplemented their conventional reading programmes with daily phonics. Lucy planned to extend this as she had been told at a phonics course that

one of the biggest determiners of a successful reader and writer is if you've had a really solid base around phonics and understand how words are put together. It makes it so much easier when you get to those stages that you don't have to think about those things. [Lucy]

Hannah reflected on some of the challenges these changes to the programme created.

We still need to get to our reading groups. At the moment I'm planning for one less reading group and...one day a week having them read with somebody. But...that's going to be really hard for us because we will probably still roam to support and settle children ... between groups and then sometimes we'll see more value on those days in terms of supporting. ... There are limitations - when I [say] "Oh, we can alternate" there's so many kinds of timetabling things. Alternate reading days - but then the kids would only get to read...two days a week and that's not enough. So, there's a lot of assumptions and things that we grapple with when we make those kinds of decisions. And yeah, it's not perfect. [Hannah]

Some of the teachers in this study also changed the way they approached the teaching of writing. Pat and Olive did no formal teaching of writing at all. However, they included short written activities in their formal phonics sessions and provided a wide range of writing materials and tools for students to use during play. Pat explained what they noticed since they made this change.

We noticed in here that they want to write because we never force them to write, we never you know. They write because they like it, they want to do it... and we never have issues 
with writing, that they don't want to write, because it's never been forced on them. [Pat]

Writing in Bonnie's class could take many forms. Sometimes it was more formal and linked to the inquiry topic, for example, a science report. However, most of the time it was led by what the students were willing and able to write about. For those students who were not yet ready to write, Bonnie did oral storytelling where the students sat and drew a picture and a teacher, or other adult, recorded the story of the picture underneath it. Here she explained the benefits of this approach.

... some... aren't ready and then we do the oral storytelling. So, ...they sit there, and they draw a picture and that of course increases their fine motor skills and [we] have little drawing sessions where they just draw... and honestly over the year that you've got them their fine motor skills are amazing. Rather than getting a worksheet with " $d$ 's" on it like we used to and going "Copy this". It doesn't mean anything to them, they don't know what a letter is ... [Bonnie]

Hannah, Lucy and Bonnie had opportunities, when they were working in teams with other teachers, to organise their time so that one teacher roamed among the students during play sessions while the other teacher, or teachers, met with groups of students. Pat and Olive, on the other hand, both roamed during play sessions and did minimal formal teaching during this time. The teachers found this roaming time invaluable as it gave them opportunities to observe what the students were showing an interest in, and to consider what the next steps might be.

...that's what we did most of last year, kind of having a couple of blocks where two teachers grabbed reading groups, one teacher roamed, supported, wrote down ideas, we were learning as a team all about urges. [Hannah] 
As indicated above, when play was part of the classroom programme, it impacted on the time available for explicit teaching of core curriculum subjects, and adaptations to the way these learning areas were taught had to be made. Planning in a play-based classroom was also a challenge.

\section{Adaptations to planning}

Participants in this study agreed that play had changed the approaches they took to planning and the way they worked with the curriculum. When the classroom programme was based on the changing and developing needs and interests of students, it could not readily be planned in advance. Teachers were learning to be flexible in the way they recorded the learning that occurred in the classroom.

One of the biggest changes the teachers in this study were making was the way they used the curriculum. In the past they would have planned ahead for all learning areas with termly, weekly, and daily plans covering specific pre-determined areas of the curriculum. They found they had moved away from following step-by-step plans and knowing in advance what they were going to teach. Instead the teachers were all more likely to do backward or retrospective planning. Pat described the process in this way.

We...set the provocation....We [were] looking at chemical and physical changes and we brought in ice cubes for them and we talked about melting them... They were exploring they were smashing them on the ground, melting them in their hands, and they were coming to the conclusion[s] themselves. We tried to question them - so we were just directing them by questions rather than giving them the knowledge and they were finding it out themselves and they were because it was a really cool session because it was truly discovery. And then we could go back to our planning and say "Oh, we covered this, we covered that". [Pat] 
Planning for writing also changed when students were given agency, or the writing emerged during play. As Bonnie explained,

... you can't really plan. It's interesting because you know how they talk about the back planning?...Planning for reading is easy because you've got your groups. Writing, you've got your idea, if you want to link it into your inquiry, which we do... sometimes, but you've also got student agency so you can't sit there and write a plan and pre-empt what 20 kids are going to write about. You do have to go back. [Bonnie]

Backward planning, or retrospective planning, requires teachers to have an in-depth knowledge of the curriculum and to make connections between what is observed during the play sessions and what is in the curriculum. Two of the teachers in this study, whose journeys into play had begun more recently, found that developing this skill was one of the more challenging aspects of implementing playbased learning. Lucy, in her first year of incorporating play into the classroom, noted that she was aware that teachers in play-based classrooms "get very knowledgeable on the curriculum...if you are doing it properly because you have to learn all of, everything" [Lucy] and one of her

next steps...is linking [the play] more to the curriculum and going back in and seeing where the next steps are and putting provocations up that will go with those sorts of things". [Lucy]

Hannah, in her second year of play-based learning, noted that while she believed the curriculum was flexible enough to allow interpretation, using it in a play-based classroom "is a bit more organic" and "does require a fairly high level of teacher competency" [Hannah]. She talked about the challenges involved in integrating play with the curriculum. 
I'm still getting there in terms of being able to ...bring... all aspects of the curriculum together, through an authentic kind of hands on play context. Not quite there yet because it's really big and it's really hard. [Hannah]

Interestingly, the other three teachers, who have been using play in their classrooms for longer, commented that Te Whäriki, the New Zealand Early Childhood Curriculum, would be a better fit for playbased classrooms. Pat and Olive had become familiar with Te Whāriki through their involvement in a local group of kindergarten and new entrant teachers whose focus was on transitions to school. During an ERO visit to their school they were asked about student progression from early childhood to school and whether they were using Te Whäriki or the NZC. ERO seemed pleased that they had adapted their programmes so that the school was ready for the children rather than the children being ready for school. Pat described their approach to using Te Whāriki:

We are using [Te Whāriki] for our own sake because we think it's... the best for the children if we do know a little bit. But we need to remember that we are primary school teachers and we are responsible for the delivery of the curriculum...It's hard you know, because you're pulled both ways... The heart tells you something else but... [Pat]

Bonnie also stated that she "would like to see more of Te Whāriki brought into the new entrant year and possibly year one. It's something I am working on..." [Bonnie].

Planning in a play-based classroom requires teachers to have a strong knowledge of the curriculum and a clear understanding of the connections between the curriculum's learning areas and what they notice their students are doing in their play. Assessing and reporting on how and what students are learning in a play-based classroom also presents challenges for teachers. 


\section{Assessment in a play-based classroom}

All the teachers in this study continued to assess their students using formal methods, as this information was required by their schools. Assessment information was used as base-line data, to identify "target" students who needed more support, for reporting purposes, and to demonstrate to ERO that they had evidence-based measures of achievement and progress in place. Teachers in this study were all grappling with the tension between these requirements to formally assess students in year one and the open-ended, student-led nature of play-based learning.

Some of the teachers in this study commented on the legacy that National Standards had left in their schools. They felt that the expectations that were set for students, particularly those who had been at school for only one year, were unrealistic; and they were relieved when the standards were revoked. They found, however, that some of their colleagues and leaders still expected students to reach the same levels of attainment, within the same time frames, as the National Standards expectations. Lucy had concluded from attending workshops and from her reading and research that "...too much of a push early on and getting the kids to a certain level by a certain time is causing all sorts of mental health issues later on in schooling and in life..." [Lucy]. Bonnie was frustrated that colleagues who taught students at the year level above her were working from a deficit model of student achievement and were more concerned about students not having certain alphabet knowledge or not being able to complete certain tasks than they were about their welfare.

Even though National Standards have gone, expectations are still there. You know in the old days "Well they can't rule a red line under a blue pen date." and "They can't do 
this." As a teacher in a staff meeting and that's all you're hearing you just sit there and go "Oh, I've really failed." ...let's just forget about the child's happiness and wellbeing and all the other things they can do and focus on the fact that they can't rule a red line. [Bonnie]

During the eight years that they had been required to use the standards, the teachers also felt that there was a negative impact on the way that achievement and progress was reported to parents.

You sat with a five year old and the parents of a five year old after they'd been at school for 20 weeks and it was like, well they're not quite there and they're below, even though you might not use that word. It's so negative, so negative. [Bonnie]

Olive, when thinking back about National Standards, found it

unbelievable...that we were pitching five year olds against the standards. We were saying after six months at school whether they were at or below. Or well below. Who are we to make that judgment? [Olive]

Teachers in this study were moving away from being focused on students getting to a particular level by a certain age, or after a certain amount of time at school. They wanted to provide an environment that supported students to develop and achieve at their own pace. However, they continued to feel pressure to assess students against a standard which created tension for them. Even in schools where teachers felt they had been freed up to use an approach more suited to the students' needs since the removal of National Standards, its influence remained.

I think [the removal of National Standards has] enabled us to teach reading the way we are teaching it now, so doing the [commercial] phonics approach where, it's still in the back of our minds, these children have been at school a year, where would they be on the reading wheel? But it is giving us the freedom to go with their progress as they are making it. But it's quite - it's quite a big challenge for us to do that. [Olive] 
Many of the teachers in this study felt that the removal of National Standards was an opportunity to reconsider appropriate levels of achievement for young students and they felt discouraged that their schools continued to want to uphold what they generally considered were unrealistic goals for students.

The teachers in this study had also been questioning the need for formal assessments conducted after six weeks at school, and after one year at school. It is common for teachers to meet with the parents, caregivers and/or whānau of a student after they have been at school for six weeks. During this meeting the teacher lets the parents know how well their child has settled into school and also provides academic information about their literacy and numeracy skills. Some of the teachers in this study had been querying the importance of reporting on student academic achievement at these meetings.

\begin{abstract}
Well what are we looking for when we do those 6 week assessments when they start school? Is it really fair to sit someone down and go "Right, what alphabet letters do you know?" No, it's not. I do get that we need to have ...some type of [tracking] but does it have to be when they've been here six weeks? So ...it's shifting in our thinking. What is the point? What are we really wanting to know with these little five-year-olds?... and all parents really want [to know] when you have those six week conversations are "Are they happy? Are they making friends?" They don't really want to know about [how many letters of the alphabet they know]. [Bonnie]
\end{abstract}

Students in New Zealand schools are usually assessed on their literacy skills after about one year at school, which is typically on or around their sixth birthday. Teachers use An observation survey of early literacy achievement (Clay, 2019), more commonly known as the "Six year net", to ascertain detailed information about approaches the student is using as they are learning to read. In some schools this 
information is also used to determine which students would benefit from being part of a reading support programme. As part of questioning the need to formally teach students prior to them turning seven, teachers in this study had also begun questioning the need to assess students in formal ways before the age of seven. The teachers in this study had all begun to feel that students who had been identified as needing some sort of support in their first two years of school, or who were struggling academically, were simply in need of more time to develop and to be ready for more formal learning.

Some students just need more time. Like it's so hard to tell that to parents. You're like "They're going to get there." I know we've got them as a focus student and we're working on accelerated learning but really what they need is just a little bit more time, you know, so we need to find that kind of balance with those children. [Hannah]

In Bonnie's school one of her colleagues had begun asking whether students needed to be given the "Six year net" when they turned six, while Olive noted that:

It sort of makes a joke of [reading support programmes] now doesn't it? Because, wow, we were taking those children at six when perhaps they would have been all right. [Olive]

All the teachers in this study had been exploring ways to record the learning they saw happening in their classrooms during play. Lucy highlighted the stresses that teachers faced when considering how to assess students in a play-based classroom.

Well, when you talk to people [who are introducing play into their classrooms], that is the one thing that they find the hardest. The recording and the assessment of play. How do you do that? And without doing your head in, without it being ridiculous, that you've got a clipboard with you all the time. [Lucy] 
A number of the teachers initially created their own observational recording sheets, based on key competencies, skills or urges. However, they found that as they attempted to record daily or weekly information about every child or every skill, they often "ended up busting [their] boilers" [Bonnie]. As a result, they pared their observations back by either focusing on a single key competency each week, selecting a smaller number of children to observe each day, or refining their observation schedule to align it with the way the school reports to parents. In some schools the teachers had moved away from assessing students after being at school for a certain period of time and were instead assessing them when the teachers felt they were ready.

The teachers in this study often felt frustrated about the expectations placed on their young students, as they had become increasingly aware that students who had only been at school for one year were not always ready for formal learning, and therefore formal assessments were inappropriate. As they had done with their planning, teachers were continually reviewing and refining assessment practices in their classrooms looking for ways to make them more congruent with a play-based curriculum, and to record the progress and achievement of their students in a meaningful way that could be shared with others.

\section{Teachers have changed their beliefs about teaching and learning}

The changes that teachers had made to their practices - the way they set up their classrooms, the way they planned, and the way they assessed - reflected the changed beliefs they had about teaching and 
learning. One of the major shifts in thinking that teachers had was on the focus of learning, which had moved away from the teacher and towards the child. Olive summed up this shift.

Rather than trying to make it the learning that's coming from my head, and forcing it on them, it's about...just letting them decide for themselves. And then the more [we] read about the benefits of free play... that allowed us to sit back a bit more I think as well. [Olive]

This change in thinking was reflected in a number of ways. Teachers in this study had come to believe that the process of learning was more important than the product. They also believed that the development of social skills, oral language and key competencies was of greater importance for young students than academic skills. Most importantly, however, they saw their role in the classroom changing.

Several teachers in this study commented on how the process of learning had become more important than the product. Previously they would have been focused on the final outcome of a task that a student was carrying out whereas they could now see that the learning came from the process that the student was following.

\section{And it's all about the process, it's not about the product. It's all about that working through and extending themselves and learning about something that they are really interested in. [Hannah]}

This conversation between Pat and Olive demonstrated the shift in thinking that they had experienced as a result of introducing playbased learning into their classrooms.

Pat: What we found in this journey [using]...open-ended activities - [the students] are not necessarily worried about bringing the finished product - they are just happy to talk about building something, not necessarily having something to show you. 
Olive: And you'll see that in the stuff that's left behind. So they might spend a whole morning making something at the making table-THAT was the journey, that was where they got the learning - the best part of the learning from - and it'll often sit on the shelf or at the front of the room and [they will be] kind of not be bothered about it. And the same with the paintings. Some days they are hell bent on taking their painting home, other days they'll just sit there and end up in the bin, but it's been the painting.

Pat: It's about the process not about the finished product.

Olive: That was new learning for me, that was real new learning for me. I was probably more product focused, end result focused, rather than the journey, when I look back on my teaching.

The teachers in this study all believed that play-based learning offered the opportunity for students to develop their oral language, and their social skills. They noticed that when students were playing, they were using language to describe, instruct, or connect with other students.

To watch them out there, if we put pots and pans and things out there and water and to hear the language that they are using, to watch how they're pouring, they're measuring, they're putting the funnel in, they're putting solid stuff through - solids and liquids - it's endless the conversations, and the interactions that they have. [Olive]

All the teachers also noted how well suited a play-based environment was for the development of social skills. As Hannah explained, she no longer had to create artificial scenarios for the teaching of social skills because they arose naturally during play. Her biggest challenge was finding the time to help the students reflect on the issue after the play session and assist them in learning from the experience.

There is no more useful way for ... social coaching of kids as learning through play. Because ... you don't have to 
create problems because they are going to have them. They come up just naturally. And they are a pain - "Gosh, I'm trying to take my reading group, this is a pain". They do crop up, but they are such good opportunities for real. I know in the past we might have taught social skills and we would have specifically created a challenge. [Hannah]

Pat and Olive felt frustrated by a lost opportunity to teach social skills to students in their school. Their colleagues had banned students from playing with a large pile of logs and branches due to the arguments that they were mediating. For Pat and Olive this situation was seen as an ideal way to help students develop skills such as resolving disputes, sharing, and compromising. "This is what we teach them [in a play-based classroom]" [Pat] explained to her colleagues.

A play-based learning environment enables teachers to meet the emotional needs of their students. Olive found that having a play session first thing in the morning allowed time for students to settle into the day. She could also be available to assist students with dealing with any issues that might arise when they first arrived at school.

I had to sort out so many issues this morning. If I had groups or structure, then I wouldn't have time to sort them out. Some children need time to settle in the morning. Play allows this. [Pat]

Similarly, Bonnie found that using a "soft start" to begin the day in her classroom decreased the separation anxiety some students experienced when leaving their parents.

The children are happy and off they go, and the parents go "Oh, OK, see you later", the children are immersed in their play and it's just a lovely way around that sort of [separation anxiety]. [Bonnie]

Teachers in this study have found that a play-based classroom offered opportunities to meet the social and emotional needs of young 
students while also providing an environment where oral language skills can develop. Here, Bonnie summed up how she saw the way these skills were intertwined.

I believe that the oral language for connecting and making friends, and relating to others, all those key competencies, are displayed beautifully in a play environment. [Bonnie]

The biggest shift that teachers in this study made was in the approach they took to teaching, and the change in their perception of their role as teachers. They were moving away from teaching, as Olive puts it, "the learning that comes from my head", and instead were working towards teaching the students based on their needs and interests. The teachers were shifting away from the way they had been trained to teach, which involved rigid timetables, inflexible planning, and a focus on academic skills, and shifting towards a style of teaching that involved them observing, noticing and responding to their students.

All the teachers in this study commented that they now spent a lot more of their time in the classroom listening, observing, and really getting to know their students. Hannah had seen a change in her behaviour.

I've definitely noticed that as a teacher I'm way more observant for just little things... Before I felt like we were really rigid with our timetable and we still are, reasonably, but like we can randomly play a game ... in the middle of a block because of the noticing. ... I definitely can see that ... we are much more open in thinking about all the kids' interests and urges. [Hannah]

For Pat and Olive, not having to teach any groups during play allows us again to find out more about the [students] and then finding the way of inspiring and motivating them- 
finding what makes them tick. So definitely through this you learn a lot more. [Pat]

Lucy got the message from the course she attended which advised teachers "...to sit back and observe, you need to give yourself the time to watch, you don't have to be talking to them all the time" [Lucy].

The teachers had also been learning to recognise the interests and urges of their students. Some teachers commented that this was a skill they noticed their ECE-trained colleagues already had, and it was something they wanted to cultivate.

That's a big learning, too, for us - primary school teachers - because [our colleague] is early childhood based and she finds it easier to look for those-she's really good at finding those interests and going with it. [Pat]

All the teachers in this study found that one of the biggest changes they had made was in the way they responded to what they had noticed and recognised in the student's play. Responses to play included having conversations, asking questions, providing resources, setting up provocations, or, in some cases, doing nothing. Learning how to talk to students and ask them questions about their play were skills that all five teachers were continuing to develop. They were all aware that students learned best in a play environment where they were guided by a skilled teacher who knew what types of questions to ask, what kinds of provocations to provide, and when to let the play take its natural course. As Hannah explained,

It's just the questioning that you ask and how you ask particular questions so that you extend their oral language [and] you don't get Yes/No answers. And you broaden their thinking and you make them connect it with other things ... or you encourage them to take their learning - to extend it. [Hannah] 
The teachers all found that relinquishing control of the learning environment and allowing students to follow their own paths had been a big adjustment as it was in stark contrast to the way they were trained to teach. As Pat put it,

For us it's still a journey because ... we were trained to teach in a very different way, so it was a real discovery - a big discovery, you know, how to let go - letting it go-it's OK to let them go. [Pat] 


\section{Discussion}

This section examines the findings from this study in the context of three broad themes that relate back to the literature. The first two themes explore the transformative changes the teachers in this study made to their practices and beliefs about teaching, and the tensions and challenges they faced as they moved to play-based learning. The third theme explores the transition from early childhood education to primary school, an area that emerged from the research.

\section{Transformative change}

The teachers in this study who were transitioning to play-based learning environments had all developed a common understanding that play resulted in better outcomes when it was guided by the teacher. They understood that allowing students to play freely without the support of an adult to observe and guide them would not lead to the best results. This contrasted with some international studies in which teachers who were introducing play into their classrooms were often unsure what play-based learning looked like or how to implement it (Baker, 2014; Fesseha \& Pyle, 2016; Hunkin, 2014; Martlew et al., 2011). This understanding that their role in the classroom needed to change was transformational for the teachers in this study, and echoed the findings of several Australian and New Zealand studies (Buchanan et al., 2018; Davis, 2015, 2018; Jay \& Knaus, 2018). As a teacher in Buchanan et al. (2018) explained, "my role as the 'teacher' changed and there were deliberate actions I would need to take in order to support [the students'] play to become a rich learning experience" (p. 20). This concept of a teacher taking deliberate actions within play is often referred to in the literature as intentional teaching. 
Australia's national Early Years Learning Framework (EYLF) (Department of Education and Training, Australian Government, 2019) has developed a definition of intentional teaching. "[It] involves educators being deliberate, purposeful and thoughtful in their decisions and action. Intentional teaching is the opposite of teaching by rote or continuing with traditions simply because things have 'always' been done that way" (p. 17). Drawing on Vygotsky's theory, with its emphasis on the socially constructed nature of learning, the framework goes on to say that "...learning occurs in social contexts and...interactions and conversations are vitally important for learning" (p. 18). The framework then expounds on Vygotsky's idea of the Zone of Proximal Development (ZPD) by stating that educators “...actively promote children's learning through worthwhile and challenging experiences and interactions that foster higher-level thinking skills" (p. 18).

Two theorists, Jerome Bruner and Barbara Rogoff, who were both influenced by Vygotsky and his concept of the ZPD, have developed ways to describe the role of the teacher in this process. Bruner coined the term "scaffolding" to describe interactions between educators and learners in which the teacher helps the student access learning that they could not do so independently (Wood, Bruner \& Ross, 1976). "Scaffolding...requires the adult (or experienced peer) to shape but not dominate the learning process" (Brock, 2014, p. 45). Rogoff uses the phrase "guided participation" to describe how educators can provide direction and assistance while being involved in an activity, side-by-side, with students. She argues that it is from these shared activities and understandings between educators and students that advanced thinking emerges (Rogoff, 1995). 
The components of intentional teaching are described in many ways in the literature (Aiono, McLaughlin \& Riley, 2019; Kennedy \& Stonehouse, 2017; Weisberg, Hirsh-Pasek, Golinkoff, Kittredge \& Klahr, 2016). There are, however, some common elements amongst these descriptions, which can be grouped into two broad categories environment and interactions. The following two sections explore these two components in more detail.

\section{Environment}

In their recommendations for play provisions for children, the National Playing Fields Association (2000) states that one of the main functions of a playworker is to "...create an environment which will stimulate children's play and maximise their opportunities for a wide range of play experiences" (p. 16). Aiono et al,(2019) explain that when establishing a learning environment for play, an educator needs to consider the physical space, the resources, the management of the resources, how and when play is timetabled, and how transitions between activities are managed. They recommend the use of "...varied and multi-purpose play resources..." (p. 63), sometimes called loose parts, which can include wooden blocks, Lego, natural materials such as shells, stones, leaves, and sticks as well as larger items such as tyres and cardboard or PVC tubes. Nolan and Paatsch (2018) reported that the primary school teachers in their study had found it challenging to build up the resources for play in their classrooms and to organise the classroom space in a way that allowed students to be independent.

The teachers in this study had experienced similar challenges when setting up their classrooms for play but had been resourceful with the spaces and equipment they already had. They made conscious adaptations to their physical learning environments through the 
creative use of existing rooms, gathering their own resources or receiving donations from parents. The teachers were also starting to create collections of loose parts for their classrooms.

\section{Interactions}

The importance of teachers' interactions with students in playbased classrooms has been explored in a number of studies (for example, Chien et al., 2010; Goble \& Pianta, 2017; Milne \& McLaughlin, 2018). Chien et al.'s (2010) results suggested that free play without guidance from an involved adult was less effective for academic achievement than a student receiving "...high-quality scaffolding interactions with teachers..." (p. 1545). Further support for teacher guidance of children's self-initiated activities comes from Goble and Pianta's (2017) work. Their findings showed that pre-school students who spent a greater proportion of their time in a teacher-directed setting, rather than a free choice setting, had higher gains in literacy and language development.

A theme common to all these studies was the acknowledgement that teachers needed to use a range of playful approaches in their classrooms, including free play, child-initiated play and adult-directed play. Edwards (2017) has developed a Pedagogical Play-framework which suggests that these three different play types (open-ended/free play, modelled/child-initiated play and purposefully-framed/adultdirected play) should be valued equally and used in multiple combinations to support learning in the classroom. Each play type offers something of value to the teacher. Free play lets students explore independently and make discoveries for themselves while also allowing for teachers to observe and gain a greater understanding of their students' interests and needs. Child-initiated play gives teachers the 
opportunity to build on ideas that have come from the students and explain concepts to them. Purposefully-framed, or adult-directed play, gives teachers the chance to introduce new ideas or materials to the students.

Aiono (2017), in her article on common misunderstandings that teachers and school leaders have about play, also advocates a balanced approach to teaching in a play-based classroom. She advises teachers not to abandon all direct teaching but to have a mixture of child-led play and purposeful acts of teaching. She recommends that teachers need to learn when to leave the play uninterrupted and when to gift knowledge to their students appropriately. She refers to this latter approach as the "spray-and-walk-away" technique (para. 6). Robinson and Aronica (2015) also advocate for teachers to use a wide range of approaches in their classrooms. They state that finding the balance between direct instruction and more exploratory activities and projects “...is what the art of teaching is all about" (p. 103).

The teachers in this study were all using a range of playful teaching approaches in their classrooms and were working on getting the right balance in their practice between teacher instruction, guided play, and free play. They were mindful about finding the right time to talk to their students and question them, conscious that sometimes it was better to step back and not interfere. All the teachers used provocations as a tool for teaching and again were working on developing their ability to ask the right types of questions to support and extend student learning. Olive and Pat explained how they sometimes observed, and sometimes provoked.

Olive: Some days you don't engage at all. 
Pat: Because there is no need. Because everything is going smoothly and it's such settled play.... like the word 'provocation' because it provokes them in some way. Provokes them to problem solve, to think, ...to socialise, to share, they are learning so much without [us] ... and the less we can be involved the better probably.

Knowing when and how to become involved in students' play is one of the greatest challenges for teachers moving from using traditional methods to using more play-based methods in their classrooms. One of the teachers commented that she was impressed by educators she had seen utilising this skill, and she was learning not to intervene too much, particularly in her students' imaginative play.

Aiono (2017) writes about the use of provocations in play-based settings, explaining that this strategy is often misunderstood by teachers. Allen (2018), a New Zealand teaching principal who implemented play-based learning in her classroom several years ago, explored her understandings about provocations and invitations in one of her blogs. She found that some educators used the terms interchangeably, so she proposed a definition to help distinguish between the two. "Invitations are the environment we provide, what we choose to put in this environment and provocations are what we do based on the interests and urges we see through children playing in that environment" (para. 23). Aiono (2017) explains that teachers in play-based environments must always be observing and thinking about the play in their rooms and know when to "...introduce provocations that may serve to lift the cognitive and social skills being explored within the play itself..." (para. 8) while making sure they do not push their own agenda onto the play.

In order to scaffold learning through play, teachers need to develop a deep knowledge of their students, of the curriculum, and of 
relevant learning progressions. These in-depth understandings allow teachers to develop learning goals for their students, to make connections back to the curriculum from the play, and to provide the appropriate supports that will help their students move forward with their learning (Aiono, 2017; Aiono et al., 2019; Jay \& Knaus, 2018; Milne \& McLaughlin, 2018). This approach also requires teachers to be available, flexible, and adaptable. As Ashiabi (2007) explains, "in teacher-guided play, the teacher must continuously adapt her... actions in response to children's activity..." (p. 205).

The teachers in this study found play-based learning was more challenging than traditional teaching had been, despite perceptions to the contrary. The energy required to successfully run a play-based learning classroom was more tiring than one where students were sitting at desks. As Bonnie and Pat explained,

It's a lot of work. I know a lot of people go "It's so easy", but it's actually more sophisticated in some ways. It looks...relaxed, but actually...MORE thought goes into it. [Bonnie]

It's definitely busier. It's definitely much harder work. Learning through play is really hard work. It's full on. We are exhausted by the end of the week even though we [work part time]. It's not easier... [you have to be] available for [the students]. It's not like in the other classes where you set the activity and then you think "I've got five minutes here. I'll go and check on something. Or maybe I'll take one workshop or two." ... [I'm] on the whole time. [Pat]

\section{Tensions and challenges}

As the findings section demonstrated, the challenges for the teachers in this study included more than the demands of reconfiguring and resourcing their physical environment and transforming their understanding of their role in the classroom. More specific challenges 
that all the teachers in this study experienced included dealing with the demands of the curriculum and assessment as well as managing the expectations of colleagues, management, and parents.

\section{Curriculum and assessment}

The teachers in this study experienced tension as they sought to ensure they were covering all aspects of the curriculum in their classrooms. Some teachers felt that they had successfully integrated a range of curriculum learning areas into their play-based programmes while others were just beginning this integration. All the teachers felt confident, however, that they were using the key competencies in their programmes. Aiono et al. (2019) sum up the reality of these tensions for New Zealand primary school teachers wanting to move to play-based learning.

If children are to self-direct their play, what do teachers $d o$ and how do they teach? Add to this tension curriculum requirements such as policy, assessment, routines and achievement foci, and primary teachers might find it difficult to blend an authentically play-based approach with current primary teaching practices. (p. 59)

Similarly, in international studies, both primary school teachers in Australia, and kindergarten teachers in Canada raised concerns over what they perceived as an overcrowded curriculum (Fesseha \& Pyle, 2016; Jay \& Knaus, 2018; Nolan \& Paatsch, 2018). Teachers in these three studies lamented the pressure they felt in having to fulfil all the requirements of the curriculum while still allowing for play. Nolan and Paatsch (2018) noticed that the two teachers in their study "...spoke of ensuring they were 'covering' all the curriculum content that was expected at this year level" and "they felt a definite need to check that academic learning had taken place during play" (p. 49). This often led the teachers to direct the students' choices during play to ensure they 
were engaging in an activity in the way the teachers intended, reassuring them that some form of academic learning was taking place.

It is not just ensuring curriculum coverage, but it is the ongoing assessment of progress against curriculum objectives that can be a challenge for teachers in play-based classrooms. Once students start school, the focus of learning shifts towards the attainment of more academic skills such as reading and writing abilities or maths knowledge. These skills are often taught and assessed using more formal methods which can conflict with the emphasis on the development of social and emotional skills in a play-based classroom, which can be more unquantifiable.

The teachers in this study were conscious of the need to monitor the progress students were making in their first year of school. They were aware of level one curriculum expectations, especially in the areas of literacy and numeracy, and tracked the progress of their students relative to these. They experienced further tensions when it came to assessing their students. Many continued to formally teach and assess some subjects, such as reading and writing, although some had begun questioning the necessity for some historical literacy assessments. The teachers were all looking for meaningful ways to record the learning they observed in their classrooms. Several had experimented with checklists or used observational data. Surprisingly, none of the teachers in this study mentioned the use of narrative assessments, widely used by early childhood teachers in New Zealand (Aiono et al., 2019). Learning stories were created by Margaret Carr, one of the co-creators of Te Whāriki. They are based on structured observations, which are interpreted and analysed and used for further responses (Ministry of Education, 2009). One of the original reasons for their development was 
to smooth the transition from early childhood to school by providing information to primary teachers on the learning dispositions of students (May, 2011).

As indicated in the literature review, these tensions were also experienced by teachers in international studies. They, too, were concerned about how to gather assessment data in play-based classrooms, and were not always confident that what they gathered was rigorous. Finding time to collect tangible data often conflicted with the need to set up, and engage in, play activities with their students and some teachers were unsure about the form this data should take. Like the teachers in this study, many had experimented with different ways to document learning including observational notes, photographs, and narratives.

\section{Colleagues, management and parents}

Teachers who are moving from using traditional ways of teaching to using play-based methods in their classrooms require the support of their school management, their colleagues and their parent community. While the teachers in this study all felt supported by their senior leadership teams, some also felt pressured to continue ensuring their students were attaining expected achievement levels in literacy and numeracy. This pressure meant that the teachers often elected to teach those learning areas in more formal ways, usually by withdrawing students for group sessions while the rest of the class engaged in play.

The teachers in this study were all fortunate enough to have at least one colleague with whom they were sharing their journey into play-based learning. This meant that they had someone with whom they could discuss ideas and challenges as well as someone who could 
provide moral support. Lucy appreciated team teaching with a colleague who "...was really on board with [play-based learning] and...100\% on the same page about how things work in the classroom which [was]...such a relief".

The experiences of teachers in this study are similar to those in both national and international studies. The teachers interviewed in Jay and Knaus (2018) commented that having supportive line managers and colleagues to share the journey with were some of the most helpful forms of support for them as they introduced play-based learning into their classrooms. Blucher et al. (2018) found similar results in their case study of one school's enactment of play-based learning in a new entrant classroom. "Support from the principal, parent-teacher association (PTA), board of trustees, and Year 1 team was vital for the successful implementation of a [play-based learning] approach" (p. 57).

Aiono (2017) points out that when teachers implement playbased learning in their classrooms this can also pose challenges for senior managers who need to upskill themselves in order to support their teachers. Not only do senior managers need to be able to identify quality play-based learning so they can appraise their teachers, but they also have to "...feel confident in being able to field any questions or concerns by their parent community" (pp. 3-4). She argues that teachers and management need to work together as a team in order to successfully implement a learning-through-play approach.

Having someone in their classroom or school with early childhood training or experience had also been particularly helpful for some teachers in this study, which paralleled the findings in two Australasian research papers. The school in Davis' (2015) study had employed two early childhood teachers as teacher aides in their new 
entrant class and they had "...proved to be invaluable...not only for their skills in presenting and creating play opportunities for children, but also for...[showing the teachers ways] to engage in rich conversations with children" (p. 11). These sentiments were echoed in Jay and Knaus (2018), where one teacher noted that it was helpful when "...another teacher with experience and specific training had joined the team, and had...made a strong contribution to the ideas and approaches that others implemented" (p. 120).

While the teachers in this study found supportive colleagues among those who were teaching the same year level as them, they did experience some questioning, or lack of understanding, from colleagues who taught at other levels of the school. Lucy experienced some push back from the teacher at the level above her who used a more structured approach in her classroom while Bonnie found that the teachers of senior students in her school wanted more information about play-based learning as they did not really understand it.

This, again, echoes the experiences of teachers in some international studies who found that colleagues did not always appreciate the effort that went into running a play-based classroom. The teachers in Nolan and Paatsch's (2018) study thought that their colleagues did not fully understand the value of play-based learning. Their fellow teachers seemed to believe that all they were doing was having fun, and the teachers felt they had to defend their decision to use play-based teaching approaches and justify what they were doing as being valid practice.

Most of the schools in this study have also found it necessary to educate their parent community about the value of play-based learning. This has been achieved through meetings or the provision of research 
and information about the benefits of play-based learning. Pat and Olive found that not only were they educating themselves and confirming that play-based learning was the best option for their students, but they were also educating their colleagues and their community. Having been successful in traditional classroom environments, parents often could not see the advantages of play-based learning, viewing play as "mucking around" and not real learning. Their school even "...had a few parents pulling their children out and putting them somewhere else because they didn't agree with [play-based learning]" [Pat].

A lack of understanding about the value of play-based learning was a theme in several international studies (Gray \& Ryan, 2016; Hegde \& Cassidy, 2009; Nolan \& Paatsch, 2018). As they had done at Pat and Olive's school, parents in these studies had based their expectations of school on their own experiences, and on the belief that school was a place for learning to read and write while home was a place for play. Because of these misunderstandings the teachers in these studies found themselves educating their communities about the validity and value of play. As one teacher explained it, "We have to continuously hold workshops for parents and explain [play-based education] to them" (Hegde \& Cassidy, 2009, p. 374).

In their workshop on play in the classroom, Cheer and Skjottrup (2019) explained that the journey into play-based teaching was exhausting for teachers because not only were they making changes to their own practice and feeling conflicted, they were also trying to convince management, colleagues, and parents about the merits of playbased learning. Pat and Olive reflected on this aspect of their journey.

Pat: Sometimes I think it would be easier if I just stuck to the old ways. It definitely would be. My life would be much 
easier because it was such a big...fight. It was educating the parents, educating the colleagues, educating our leadership, educating ourselves, so it was a massive journey.

Olive: All of the reading, all of the research that we did to support what we were doing, to gain the knowledge that we needed as well, but also to keep proving to everyone else. Have you read this piece of evidence? Have you read that? There's a lot of time... [and] a huge amount of learning for me with all of that research that I did, but it's an exhausting way to teach.

Pat: But knowing now what we know, we would never go back.

\section{Transitioning to school}

The changes that early years teachers are making to their practice have clear implications for the transition from early childhood education to primary schools.

One of the reasons the teachers in this study were introducing play-based learning into their classrooms was because they believed it helped smooth the transition to school. While this rationale was rarely mentioned in the international papers reviewed for this study, it was a common motivation in the New Zealand literature (Blucher et al., 2018; Buchanan et al., 2018; Davis, 2018; Hedges, 2018; Hiini et al., 2018; Milne \& McLaughlin, 2018). Davis (2018) found teachers were motivated by a strong interest in providing "...greater continuity in learning and experience from early childhood education to school..." (p. $30)$.

One of the teachers in this study commented that "it really was true that the jump between, or the gap, or the difference between early childhood and school...was a big shock for the kids" (Bonnie). However, after introducing play-based learning into her classroom, she observed 
that many of her students, who may previously have been anxious about the transition to school, seemed calmer. Another teacher commented that parents at her school had seen how happy their children were when they transitioned from kindergarten because they were moving to an environment which was known and comfortable. Teachers and parents in several of the New Zealand studies had also noticed that their students were happier and more settled as a result of starting school in a play-based classroom. Peters, Paki and Davis (2015), found that difficulties students had when transitioning to school were more likely to be about "...navigating [the] difference in the kinds of learning that were expected and valued in ECE and at school..." (p. 14). By providing a space that is similar to that of their early childhood service, with familiar routines and experiences, teachers can help students to feel a sense of belonging at school, easing the shift to a new environment.

Pat and Olive were part of a local transitioning group of new entrant and kindergarten teachers which met termly to discuss a range of common issues. They found these meetings helped them understand more about how the early childhood curriculum was used and to identify ways they could progress students when they arrived at school. Having early childhood services and schools working together as equal partners was one of the suggestions made in an ERO (2015a) report on successful transitioning practices.

Bonnie expressed interest in exploring the use of Te Whāriki as a curriculum for teaching year one and two students. Margaret Carr (2006) has been advocating this approach for several years. She suggests that teachers make more use of the connections between the strands and learning dispositions of Te Whāriki and the key 
competencies of the NZC to promote continuity between early childhood education and school. The NZC (Ministry of Education, 2007) itself includes a subsection on learning pathways containing a diagram that shows the connections between the two documents, while the revised edition of Te Whāriki (Ministry of Education, 2017) devotes a whole chapter to pathways to school and kura. In this chapter the parallels between the principles and approaches of Te Whäriki and the NZC are highlighted. The section also includes an extensive table demonstrating the "...ways in which the key competencies, values and learning areas of the New Zealand Curriculum build on the learning outcomes of Te Whāriki" (p. 52).

NZC Online’s (Ministry of Education, 2019b) blog “Learning through play - What's it all about?", summarises the way play-based learning can provide a link between Te Whāriki and the ideals expressed in the $N Z C$.

Learning through play can help schools realise the vision of The New Zealand Curriculum and support students to develop values, key competencies, and understandings across all learning areas. (para. 5)

Learning through play also provides the opportunity to extend the use of our Te Whāriki curriculum into primary schooling. Te Whāriki encourages primary teachers to weave the principles and strands of the early childhood curriculum with the values, key competencies, and learning areas of The New Zealand Curriculum as children engage in learning experiences. This will enable our young learners to experience joined-up transitions between settings. (para. 6)

Peters (2010), in her literature review on transitions from early childhood education to school, also suggests that teachers provide “...opportunities for play that enable children to explore experiences, develop language and foster understanding and meaning..." (p. 3). Hiini 
et al. (2018) note that teachers in their network "...work to teach NZC through the key competencies as well as combining principles from $T e$ Whāriki" (p. 71).

Several teachers in this study argued for there to be a shift in thinking from an expectation that students be ready for school towards an approach that puts an emphasis on schools being ready for students. In its 2015 report, ERO (2015a) noted that, over time, the research literature has begun to reflect this change in philosophy and it goes on to state that "schools must have practices and policies that assist children and their families to comfortably move from preschool to primary school" (p. 9). Going to school is likely to be the first major transition a child experiences (Peters et al,, 2015). If this transition is not positive it can have ramifications for a student's sense of self and continuing school success (Education Review Office, 2015a). Teachers who are using a play-based learning approach in the early years of school are not only smoothing this transition but are helping to prepare students for a positive school experience in the future. 


\section{Conclusion}

This thesis has provided a detailed account of a study into the experiences of a small group of primary school teachers as they transitioned to using play-based practices in their new entrant classrooms. A qualitative approach was used to answer the four research questions.

\section{Summary of findings}

What pathways have teachers taken in their transition to a playbased classroom?

All the teachers initiated the use of play-based learning, most often in collaboration with a colleague at the same year level. The journey was rewarding but also challenging, with teachers finding themselves justifying the use of play-based learning to management, colleagues, and parents.

\section{What are the reasons teachers of students in years one to three are transitioning from traditional to play-based classrooms?}

The main reason teachers were transitioning to play-based learning was their growing appreciation of the developmental appropriateness of a play-based environment for their students. This understanding had come from their own research into child development and neuroscience. They felt that having a play-based focus in the first year of school would ease the transition from early childhood education to school by providing a familiar environment for the students. 


\section{What changes in practice have teachers made as a result of this}

transition?

The teachers in this study had made changes to both the physical environment and their classroom programmes as a result of their move to play-based learning.

\section{What changes in beliefs about themselves as teachers have occurred as a result of this transition?}

A less obvious transformation the teachers in this study had made was in their perception of their role in the classroom. The focus of their teaching had shifted away from a style of teaching that was centred around achievement objectives and learning outcomes towards a teaching approach that was based on student interests and motivations. This change had been one of the greatest challenges for them.

\section{Implications for policy and practice}

This study has identified a number of challenges that face teachers who are implementing play-based learning in the early years of primary school. There are opportunities for improvements to both policy and practice that would assist other teachers considering this transition.

\section{Policy}

Recommended changes to policy emerging from this study include rethinking curriculum and assessment practices for the first two years of school, ensuring teachers have sufficient time and suitable class sizes to successfully implement play-based learning, and providing appropriate professional development. 
The government is currently reviewing many aspects of the New Zealand education system, including the years 1-13 curriculum (Education Conversation/Kōrero Matauranga, n.d.). New Zealand prides itself on having a flexible curriculum that can be interpreted to suit the needs of individual schools (Peters, 2010). In the subsection on learning pathways, the NZC (Ministry of Education, 2007) states that "Schools can design their curriculum so that students find the transitions positive and have a clear sense of continuity and direction" (p. 42). The curriculum also includes references to the connections between the strands of Te Whāriki (Ministry of Education, 2017) and the key competencies of the NZC (Ministry of Education, 2007). The NZC Online blog "Connections between the NZC and Te Whāriki - Part 2" (Ministry of Education, 2018b) poses the question "Should the framework of Te Whāriki move into the junior school? What shifts in thinking are required?" (para. 7). The curriculum review, therefore, should consider formally positioning the first two years of schooling under the umbrella of the early childhood curriculum, Te Whāriki (Ministry of Education, 2017).

Despite the flexibility of the existing curriculum, teachers who are implementing play-based learning find themselves challenged to prove the effectiveness of play-based learning. This is due to the lingering shadow of National Standards even though it was removed at the end of 2017. School leaders, teachers, and school communities continue to hold inappropriate expectations regarding literacy and numeracy achievement levels for five to seven-year-olds. As the teachers in this study have come to realise, new entrant students need to have a curriculum that focuses on their social and emotional development, not their ability to read or write at a particular level by a certain time. The government would do well to look back at New 
Zealand's own history of having specialised infant classes with teachers trained in the use of play as a form of learning as they consider the way forward.

If the government were to mandate the use of Te Whāriki (Ministry of Education, 2017) in the early years of primary schools, there would also need to be a parallel shift away from the use of formal assessments and reporting for this age group. The government could assist schools by providing them with alternate ways to assess and report on the progress of students with a stronger emphasis on the five strands of Te Whāriki (Ministry of Education, 2017) and the five key competencies of the NZC (Ministry of Education, 2007). Two recent reports from the ERO on the integration of key competencies into school curricula (Education Review Office, 2019a, 2019b) are an indication that a focus on developing and assessing student capabilities rather than academic achievement is already underway. Play-based learning, while not specifically mentioned in either of these reports, can certainly be part of the recommended systemic change.

As teachers in this study and elsewhere have reported, playbased learning is more time-consuming than teaching in a traditional classroom. Time is needed during play to talk with students, get to know them and understand their interests, knowledge, and motivations so that appropriate programmes that extend and challenge their thinking can be developed. Peters (2010) observed that “...a smaller class is likely to support teachers in getting to know children and...to take a proactive role in scaffolding children's thinking and supporting their transition to school" (pp. 59-60). The current staffing ratio for year one students in both Māori immersion and non-Māori immersion classes is 1:15 (Ministry of Education, 2019a), which allows teachers to 
develop strong relationships with their students. The ratio for nonMāori immersion classes jumps dramatically to 1:23 in year two. It is recommended that ratios for both new entrant and year two classes be set at 1:15, to allow teachers to develop the sorts of relationships that effective play-based learning demands. The ability to appoint additional teachers to maintain these ratios as the school roll grows, should also be reviewed, with existing early childhood education guidelines taken into consideration.

Teaching in a play-based classroom requires teachers to develop a different approach to their teaching. Learning to teach with intentionality often involves unlearning previous ways of teaching and embracing a philosophy of noticing, recognising, and responding to students' interests and urges. To ensure teachers know about the most effective ways to include play in their classrooms, and to understand its value, it is suggested that play-based learning and an understanding of Te Whāriki (Ministry of Education, 2017) become compulsory subjects in Initial Teacher Education programmes for primary school teachers. Specialised courses could be made available for those wanting to become early years teachers. In addition, play-based learning should become one of the specialisations of the Ministry of Education's Professional Learning and Development facilitators (Ministry of Education, n.d.).

\section{Practice}

Aiono et al. (2019) realised that there was a lack of relevant evidence-based information available for New Zealand teachers wanting to become more intentional in their practice. In response to this need for "...a clear set of evidence-based teaching through play strategies and a method for observing these strategies" (p. 61) a Play- 
Based Learning Observation Tool (P-BLOT) has been developed (Aiono \& McLaughlin, 2018). This set of checklists allows teachers to evaluate where they are in their play-based learning journey, to identify areas of strength, and to prioritise areas for future development. This useful tool covers three broad areas - the learning environment, teacher behaviour, and overall teacher practices (Aiono et al., 2019). It is recommended that teachers use this tool to formatively assess their current practice and make appropriate changes. The tool also provides a valuable source of information about what constitutes effective playbased learning that school leaders could use to guide them when appraising teachers in play-based learning classrooms.

One of the P-BLOT checklists covers the assessment and communication of student progress, suggesting that teachers use narrative assessments to record observations relating to both the key competencies, and specific learning areas of the curriculum. None of the teachers in this study were using narrative assessments as a method of communicating learning progress to their parent community. They tended to use existing school formats, many of which had a focus on the acquisition of academic skills, and were often better suited to the more formal, instructional style of teaching that they had used in the past. Teachers who are adopting play-based learning practices will also need to change the way they assess students and record their learning which may require additional professional development support.

One suggested strategy for easing the transition from early childhood education to the school environment is for staff in both sectors to work together as equal partners (Education Review Office, 2015a). Teachers need to become more familiar with the curriculum, pedagogy, practices, and expectations in each other's environments. For 
primary teachers this would mean developing a deep understanding of Te Whäriki (Ministry of Education, 2017) and the links between its strands and learning dispositions and the NZC's (Ministry of Education, 2007) key competencies. This could be achieved through open conversations with early childhood educators, visits to early childhood education centres, and further professional development.

\section{Strengths and limitations of this research}

There are both strengths and limitations to the methodology used in this study. Thematic analysis of qualitative data gives a "...rich and detailed, yet complex, account of data" (Braun \& Clarke, 2006, p. 78 ) and captures the unique features of the participants' experiences. The use of multiple data sources allows for the gathering of contextual information and assists in situating the participants in their environment. The use of low-inference descriptors such as verbatim quotes allows the reader to "...experience for themselves the participant's perspectives" (Johnson, 2014, p. 302).

Limitations of this study include its small, homogenous sample, taken from within a single region of New Zealand, and from schools in areas of higher socio-economic status. The small scale of this study means that results are not able to be generalised. A single researcher conducting the interviews and observations does not allow for interobserver reliability (Podmore, 2006). As a qualitative study, the subjectivity of the researcher influences the development of research questions, methodological decisions, the nature of the observations, data analysis and discussion of findings (Braun \& Clarke, 2006; Podmore, 2006). 


\section{Further research}

This study has made a small contribution to the growing body of New Zealand based literature on play-based learning in the early years of primary school. As this grassroots movement gains momentum, further research into effective practice is required. Larger studies, across multiple schools with diverse characteristics, are recommended to gain a better understanding of the impact of introducing play-based learning into primary schools. Research could also focus on successful implementation strategies.

Aiono’s (Aiono \& McLaughlin, 2018; Aiono et al., 2019) recent work could form the foundation for further exploration into intentional teaching. As this study has highlighted, moving to play-based learning is transformational for teachers. Research that can help teachers better understand the nature of play and the most effective strategies for engaging with students during play would be of great benefit.

\section{Concluding statement}

The findings from this study indicate that teachers who are transitioning to the use of play-based learning approaches in their classroom would benefit from support through changes to the curriculum, and to assessment practices. An increased understanding by policymakers of the learning and development needs of students in the early years of primary school and the resources required to implement this approach would also be beneficial. 


\section{References}

Aiono, S. (2017). Play misunderstood: The divide between primary classroom. Education Review. Retrieved from https://educationcentral.co.nz/play-misunderstood-the-dividebetween-primary-classroom/

Aiono, S., \& McLaughlin, T. (2018). Practice implementation checklists (PIC). In Play-based learning observation tool research version 1.0 (P-BLOT 1.0): Manual and supplemental resources. (Unpublished instrument.). Retrieved from https://eyrl.nz/play-basedlearning-pic/

Aiono, S., McLaughlin, T., \& Riley, T. (2019). While they play, what should I do? Strengthening learning through play and intentional teaching. Не Кирu, 6(2), 59-68.

Allen, L. (2018, December 28). Invitations, provocations and backward planning [Blog post]. Retrieved from http://numberagents.blogspot.com/2018/12/invitationsprovocations-and-backward.html

Allen, L. (2019a, October 18). Beginning a journey into play [Blog post]. Retrieved from http://nzcurriculum.tki.org.nz/Curriculumresources/NZC-Online-blog/Beginning-a-journey-into-play

Allen, L. (2019b, October 21). Some misunderstandings about play [Blog post]. Retrieved from http://nzcurriculum.tki.org.nz/Curriculum-resources/NZCOnline-blog/Some-misunderstandings-about-play Ashiabi, G. S. (2007). Play in the preschool classroom: Its socioemotional significance and the teacher's role in play. Early Childhood Education Journal, 35(2), 199-207. https://doi.org/10.1007/s10643-007-0165-8 
Baker, F. S. (2014). Teachers' views on play-based practice in Abu Dhabi kindergartens. International Journal of Early Years Education, 22(3), 271-286.

https://doi.org/10.1080/09669760.2014.944884

Barber, K. (2019, Winter). Let children play. Family Times: We've Got Parenting Covered, 14-16.

Barblett, L. (2010). Why play-based learning? Every Child, 16(3), 4.

Beck, B. (2019, January). The generation game. The Economist. Retrieved from https://www.economist.com/specialreport/2019/01/03/why-childrens-lives-have-changed$\underline{\text { radically-in-just-a-few-decades }}$

Blucher, M., Aspden, K., \& Jackson, J. (2018). Play-based learning in an Aotearoa New Zealand classroom: Child, parent, teacher and school leader perspectives. Set: Research Information for Teachers, (3), 51-59. https://doi.org/10.18296/set.0118

Bolstad, R., \& Roberts, J. (Eds.). (2018). Learning through play and games [Special issue]. Set: Research Information for Teachers, 3. Retrieved from https://www.nzcer.org.nz/nzcerpress/set/set2018-no-3

Bonne, L. (2016). National standards in their seventh year: Findings from the NZCER national survey of primary and intermediate schools 2016. Wellington, New Zealand: NZCER.

Boyd, S., \& Barwick, H. (2011). Wellbeing at school: Building a safe and caring school climate that deters bullying. Retrieved from https://www.nzcer.org.nz/research/publications/wellbeingschool-building-safe-and-caring-school-climate-deters-bullying

Braun, V., \& Clarke, V. (2006). Using thematic analysis in psychology. Qualitative Research in Psychology, 3(2), 77-101. https://doi.org/10.1191/1478088706qp063oa 
Brewer, J. A. (2007). Introduction to early childhood education: Preschool through primary grades (6th ed.). Boston, MA: Pearson/Allyn \& Bacon.

Brewerton, M. (2004). Reframing the essential skills: Implications of the OECD defining and selecting key competencies project. Retrieved from https://nzcurriculum.tki.org.nz/Archives/Curriculumproject-archives/Developing-the-draft/Keycompetencies/Background-reading

Brock, A. (Ed.). (2014). Perspectives on play: Learning for life (2nd ed.). London; New York: Routledge, Taylor \& Francis Group.

Buchanan, S., Donaldson, C., Stewart, M., \& Davis, K. (2018). Building successful learning foundations: A Teacher-led Innovation Fund research project 2016-2018. Retrieved from https://waiouru.school.nz/teacher-led-innovation-fund-report/

Burghardt, G. M. (2010). Defining and recognizing play. Retrieved from https://doi.org/10.1093/oxfordhb/9780195393002.013.0002

Caillois, R. (1962). Man, play, and games. London, Great Britain: Thames and Hudson.

Carr, M. (1998). Taking dispositions to school: keynote address to seminar on transition to school. Childrenz Issues: Journal of the Children's Issues Centre, 2(1), 21-24.

Carr, M. (2006). Learning dispositions and key competencies: a new curriculum continuity across the sectors? Set: Research Information for Teachers, 2, 23-27.

Cheer, L., \& Skjottrup, J. (2019, February). Play in the classroom: A practical workshop for teachers of year 0-3. Presented at the Maungaraki School, Wellington. Maungaraki School, Wellington, New Zealand.

Chien, N. C., Howes, C., Burchinal, M., Pianta, R. C., Ritchie, S., Bryant, D. 
M., ... Barbarin, O. A. (2010). Children's classroom engagement and school readiness gains in prekindergarten. Child Development, 81(5), 1534-1549.

Clay, M. M. (2019). An observation survey of early literacy achievement (4th ed.). Auckland, New Zealand: Heinemann.

Davis, K. (2015). New-entrant classrooms in the re-making. Christchurch, New Zealand: CORE Education.

Davis, K. (2018). Playification of the curriculum: Learnings from collaborative classroom research. Set: Research Information for Teachers, (3), 28-35. https://doi.org/10.18296/set.0115

Department of Education and Training, Australian Government. (2019). Belonging, being \& becoming: The early years learning framework for Australia. Retrieved from https://docs.education.gov.au/documents/belonging-beingbecoming-early-years-learning-framework-australia

Early Life Foundations, \& The Walker Learning Group. (n.d.). What is walker learning? Retrieved from https://earlylife.com.au/aboutwalker-learning/

Education Central. (2019a, May). Learning through play. Retrieved from https://educationcentral.co.nz/learning-through-play/

Education Central. (2019b, July). Children reaping benefits of playbased learning at school. Retrieved from https://educationcentral.co.nz/children-reaping-benefits-ofplay-based-learning-at-school/

Education Conversation/Kōrero Matauranga. (n.d.). Curriculum, Progress and Achievement. Retrieved January 20, 2020, from https://conversation.education.govt.nz/conversations/curriculu m-progress-and-achievement/ 
Education Hub. (2018). A brief introduction to play-based learning. Retrieved from https://theeducationhub.org.nz/researchguide/a-brief-introduction-to-play-based-learning/

Education Review Office. (2015a). Continuity of learning: Transitions from early childhood services to schools. Retrieved from http://www.ero.govt.nz/National-Reports/Continuity-oflearning-transitions-from-early-childhood-services-to-schoolsMay-2015/National-report-summary

Education Review Office. (2015b). Wellbeing for children's success at primary school. Retrieved from https://www.ero.govt.nz/publications/wellbeing-for-childrenssuccess-at-primary-school/

Education Review Office. (2019a). Developing key competencies in students years 1 to 8 . Retrieved from https://www.ero.govt.nz/publications/developing-keycompetencies-in-students-years-1-8/

Education Review Office. (2019b). The key competencies: Realising the potential of the New Zealand curriculum. Retrieved from https://www.ero.govt.nz/publications/developing-keycompetencies-in-students-years-1-8/

Edwards, S. (2017). Play-based learning and intentional teaching: Forever different? Australasian Journal of Early Childhood, 42(2), 4-11. https://doi.org/10.23965/AJEC.42.2.01

Entin, E. (2011, October 12). All work and no play: Why your kids are more anxious, depressed. The Atlantic. Retrieved from https://www.theatlantic.com/health/archive/2011/10/allwork-and-no-play-why-your-kids-are-more-anxiousdepressed/246422/ 
Fein, G., \& Rivkin, M. (1986). The Young child at play: Review of research. Washington, D.C.: National Association for the Education of Young Children.

Fesseha, E., \& Pyle, A. (2016). Conceptualising play-based learning from kindergarten teachers' perspectives. International Journal of Early Years Education, 24(3), 361-377. https://doi.org/10.1080/09669760.2016.1174105

Fisher, R., \& Martin, B. (2006). An evaluation of the Discovery Time programme. Kairaranga, 7(2), 31-35.

Fleer, M. (2013). Play in the early years. Port Melbourne, VIC: Cambridge University Press.

Fleer, M., \& Veresov, N. (2018). A cultural-historical methodology for researching early childhood education. In M. Fleer \& B. Van Oers (Eds.), International Handbook of Early Childhood Education (pp. 225-250). Dordrecht: Springer.

Goble, P., \& Pianta, R. C. (2017). Teacher-child interactions in free choice and teacher-directed activity settings: Prediction to school readiness. Early Education and Development, 28(8), 10351051. https://doi.org/10.1080/10409289.2017.1322449

Gray, C., \& Ryan, A. (2016). Aistear vis-à-vis the rimary curriculum: The experiences of early years teachers in Ireland. International Journal of Early Years Education, 24(2), 188-205. https://doi.org/10.1080/09669760.2016.1155973

Gray, P. (2015). Free to learn: Why unleashing the instinct to play will make our children happier, more self-reliant, and better students for life. New York, NY: Basic Books.

Gunnarsdottir, B. (2014). From play to school: Are core values of ECEC in Iceland being undermined by ‘schoolification'? International 
Journal of Early Years Education, 22(3), 242-250.

https://doi.org/10.1080/09669760.2014.960319

Guo, L. (2013). New curriculum reform in China and its impact on teachers. Comparative and International Education / Éducation Comparée et Internationale, 41(2), 87-105. Retrieved from https://ir.lib.uwo.ca/cie-eci/vol41/iss2/6

Haggerty, M., \& Loveridge, J. (2019). Strengthening early childhood and school sector continuities in producing the lifelong learner in Aotearoa New Zealand. Journal of Education Policy, 34(1), 83100. https://doi.org/10.1080/02680939.2017.1410576

Hedges, H. (2018). Play-based learning: Questions and invitations from early childhood education. Set: Research Information for Teachers, (3), 60-65. https://doi.org/10.18296/set.0119

Hegde, A. V., \& Cassidy, D. J. (2009). Kindergarten teachers' perspectives on developmentally appropriate practices (DAP): A Study Conducted in Mumbai (India). Journal of Research in Childhood Education, 23(3), 367-381. https://doi.org/10.1080/02568540909594667

Hiini, V., MacKinnon, A., Lonergan, K., Spalding, D., \& Bridson, D. (2018). A regional network to develop play-based learning. Set: Research Information for Teachers, (3), 70-73. https://doi.org/10.18296/set.0121

Hipkins, C. (2017, December). National Standards ended. Retrieved October 13, 2019, from The Beehive website: http://www.beehive.govt.nz/release/national-standards-ended Hunkin, E. (2014). We're offering true play-based learning: Teacher perspectives on educational dis/continuity in the early years. Australasian Journal of Early Childhood, 39(2), 30-35.

Hyvonen, P. T. (2011). Play in the school context? The perspectives of 
Finnish teachers. Australian Journal of Teacher Education, 36(8). https://doi.org/10.14221/ajte.2011v36n8.5

Jachyra, P., \& Fusco, C. (2016). The place of play: From playground to policy to classroom well-being. Sport, Education and Society, 21(2), 217-238.

https://doi.org/10.1080/13573322.2014.896331

Jay, J., \& Knaus, M. (2018). Embedding play-based learning into junior primary (year 1 and 2) curriculum in WA. Australian Journal of Teacher Education, 43(1), 112-126.

https://doi.org/10.14221/ajte.2018v43n1.7

Johnson, B. (2014). Educational research: Quantitative, qualitative, and mixed approaches (5th ed). Thousand Oaks, CA: Sage Publications.

Johnson, B., \& Christensen, L. B. (2012). Educational research: Quantitative, qualitative, and mixed approaches (4th ed). Thousand Oaks, CA: Sage Publications.

Karlsen, L., \& Lekhal, R. (2019). Practitioner involvement and support in children's learning during free play in two Norwegian kindergartens. Journal of Early Childhood Research, $1476718 X 1985639$. https://doi.org/10.1177/1476718X19856390

Kennedy, A., \& Stonehouse, A. (2017). Victorian early years learning and development framework evidence paper: Practice principle guide 6 integrated teaching and learning approaches. Retrieved from Victoria Department of Education and Early Childhood Development. website: https://www.education.vic.gov.au/childhood/professionals/lea rning/Pages/veyldfproflearn.aspx\#link98 
Lincoln, Y. S., \& Guba, E. G. (1985). Naturalistic inquiry. Beverly Hills, CA: Sage Publications.

Liu, C., Solis, S., Jensen, H., Hopkins, E., Neale, D., Zosh, J., ... Whitebread, D. (2017). Neuroscience and learning through play: A review of the evidence. https://doi.org/10.13140/RG.2.2.11789.84963

Malterud, K. (2001). Qualitative research: Standards, challenges, and guidelines. The Lancet, 358(9280), 483-488. https://doi.org/10.1016/S0140-6736(01)05627-6

Marcon, R. A. (2002). Moving up the grades: Relationship between preschool model and later school success. Early Childhood Research \& Practice, 4(1), 2-24. Retrieved from https://eric.ed.gov/?id=ED464762

Martlew, J., Stephen, C., \& Ellis, J. (2011). Play in the primary school classroom? The experience of teachers supporting children's learning through a new pedagogy. Early Years, 31(1), 71-83. https://doi.org/10.1080/09575146.2010.529425

May, H. (1997). The discovery of early childhood: The development of services for the care and education of very young children, mid eighteenth century Europe to mid twentieth century New Zealand. Wellington: Auckland University Press/Bridget Williams Books. May, H. (2001). Politics in the playground: The world of early childhood in postwar New Zealand. Wellington, NewZealand: Bridget Williams Books with the New Zealand Council for Educational Research.

May, H. (2005). School beginnings: A nineteenth century colonial story. Wellington, NewZealand: NZCER Press.

May, H. (2011). I am five and I go to school: Earlyyears schooling in New Zealand, 1900-2010. Dunedin, New Zealand: Otago University Press. 
May, H. (2018, March). Taking Te Whäriki to school. Presented at the Taking the Lead - Celebrating our Curricula at Wellington, New Zealand.

McIvor, K. (2019, February 26). NZ has highest death rate for teenagers in developed world. In Kerre McIvor Mornings. Retrieved from https://www.newstalkzb.co.nz/on-air/kerre-mcivormornings/audio/nathan-wallis-new-zealand-ranks-bottom-ofdeveloped-countries-on-youth-mortality-rates/

Menzies, S. (2015, February). Play based learning: Producing critical, creative and innovative thinkers. Retrieved March 3, 2019, from https://educationcentral.co.nz/play-based-learning-producingcritical-creative-and-innovative-thinkers/

Middleton, S., \& May, H. (1997). Teachers talk teaching, 1915-1995: Early childhood, schools, and teachers' colleges. Palmerston North, NewZealand: Dunmore Press.

Miller, E., \& Almon, J. (2009). Crisis in the kindergarten: Why children need to play in school. College Park, Md.: Alliance for Childhood.

Milne, J., \& McLaughlin, T. (2018). Examining the teacher's role in playbased learning: One teacher's perspective. Set: Research Information for Teachers, (3), 44-50. https://doi.org/10.18296/set.0117

Ministry of Education (Ed.). (1996). Te Whāriki: He whāriki mātauranga mō ngā mokopuna o Aotearoa.Early childhood curriculum. Wellington, New Zealand: Learning Media.

Ministry of Education. (2007). The New Zealand Curriculum. Learning Media.

Ministry of Education. (2009). Narrative assessment: A guide for teachers : a resource to support the New Zealand curriculum exemplars for learners with special education needs. Wellington, 
N.Z.: Published for the Ministry of Education by Learning Media Ltd.

Ministry of Education. (2017). Te Whāriki: He whāriki mātauranga mō ngā mokopuna o Aotearoa-Early childhood curriculum.

Wellington: Ministry of Education.

Ministry of Education. (2018a, June 21). NZC and Te Whāriki - Part 1

[Blog post]. Retrieved March 15, 2019, from

http://nzcurriculum.tki.org.nz/Curriculum-resources/NZC-

$\underline{\text { Online-blog/NZC-and-Te-Whariki-Part-1 }}$

Ministry of Education. (2018b, June 25). NZC and Te Whāriki - Part 2

[Blog post]. Retrieved March 15, 2019, from

http://nzcurriculum.tki.org.nz/Curriculum-resources/NZC-

Online-blog/NZC-and-Te-Whariki-Part-2

Ministry of Education. (2019a). Curriculum staffing. Retrieved January

20, 2020, from https://www.education.govt.nz/school/funding-

and-financials/resourcing/school-staffing/entitlement-

staffing/curriculum-staffing

Ministry of Education. (2019b). Learning through play - What's it all

about? [Blog post]. Retrieved March 13, 2019, from

http://nzcurriculum.tki.org.nz/Curriculum-resources/NZC-

Online-blog/Learning-through-play-What-s-it-all-about

Ministry of Education. (n.d.). Facilitators available to deliver centrally-

funded PLD. Retrieved January 20, 2020, from

http://services.education.govt.nz/pld/information-for-

principals-and-school-leaders/filter-credited/

Ministry of Health. (2019). Office of the Director of Mental Health and

Addiction Services: Annual Report 2017. Retrieved from Ministry

of Health. website:

https://www.health.govt.nz/system/files/documents/publicati 
ons/office-of-the-director-of-mental-health-and-addictionservices-annual-report-2017-v2.pdf

Morgan, A. E., \& Kennewell, S. E. (2006). Initial teacher education students' views on play as a medium for learning-A divergence of personal philosophy and practice. Technology, Pedagogy and Education, 15(3), 307-320. https://doi.org/10.1080/14759390600923691

Mutch, C. (2004). The rise and rise of early childhood education in New Zealand. Citizenship, Social and Economics Education, 6(1), 1-11. https://doi.org/10.2304/csee.2004.6.1.1

Mutch, C. (2013). Doing educational research: A practitioner's guide to getting started. (2nd ed). Wellington: NZCER Press.

Nathan, P., \& Pellegrini, A. D. (2011). The Oxford handbook of the development of play. Retrieved from http://proxy2.hec.ca/login?url=http://dx.doi.org/10.1093/oxfo $\underline{\mathrm{rdhb} / 9780195393002.001 .0001}$

National Playing Fields Association. (2000). Best play: What play provision should do for children. Retrieved from http://www.playengland.net/wpcontent/uploads/2015/09/best-play.pdf

Nolan, A., \& Paatsch, L. (2018). (Re)affirming identities: Implementing a play-based approach to learning in the early years of schooling. International Journal of Early Years Education, 26(1), 42-55. https://doi.org/10.1080/09669760.2017.1369397

Peters, S. A. (2010). Literature review: Transition from early childhood education to school : report to the Ministry of Education. Wellington: Ministry of Education.

Peters, S., Paki, V., \& Davis, K. (2015). Learning journeys from early childhood into school (p. 20). Retrieved from TLRI website: 
http://www.tlri.org.nz/sites/default/files/projects/TLRI \%20P eters Summary $\% 28 v 2 \% 29 \% 20 \% 281 \% 29 . p d f$

Podmore, V. N. (2006). Observation: Origins and approaches to early childhood research and practice. Wellington, N.Z.: NZCER Press.

Podmore, V. N., \& Luff, P. (2012). Observation: Origins and approaches in early childhood. Maidenhead, Berkshire: Open University Press.

Pramling Samuelsson, I., \& Johansson, E. (2006). Play and learningInseparable dimensions in preschool practice. Early Child Development and Care, 176(1), 47-65. https://doi.org/10.1080/0300443042000302654

Pui-wah, D. C. (2008). Meta-learning ability - a crucial component for the professional development of teachers in a changing context. Teacher Development, 12(1), 85-95. https://doi.org/10.1080/13664530701827764

Pui-Wah, D. C., \& Stimpson, P. (2004). Articulating contrasts in kindergarten teachers' implicit knowledge on play-based learning. International Journal of Educational Research, 41(4-5), 339-352. https://doi.org/10.1016/j.ijer.2005.08.005

Puteh, S. N., \& Ali, A. (2013). Preschool teachers' perceptions towards the use of play-based approach in language and literacy development for pre-school. Malaysian Journal of Learning and Instruction, 10, 79-98.

Pyle, A., \& Bigelow, A. (2015). Play in kindergarten: An interview and observational study in three Canadian classrooms. Early Childhood Education Journal, 43(5), 385-393. https://doi.org/10.1007/s10643-014-0666-1

Pyle, A., \& Danniels, E. (2017). A continuum of play-based learning: The role of the teacher in play-based pedagogy and the fear of hijacking play. Early Education and Development, 28(3), 274- 
289. https://doi.org/10.1080/10409289.2016.1220771

Pyle, A., Poliszczuk, D., \& Danniels, E. (2018). The challenges of promoting literacy integration within a play-based learning kindergarten program: Teacher perspectives and implementation. Journal of Research in Childhood Education, 32(2), 219-233.

https://doi.org/10.1080/02568543.2017.1416006

Rieber, L. P. (1996). Seriously considering play: Designing interactive learning environments based on the blending of microworlds, simulations, and games. Educational Technology Research and Development, 44(2), 43-58.

Robertson, D. (2018, April). Kaimai School-Play based learning. Retrieved May 5, 2019, from http://nzcurriculum.tki.org.nz/Curriculum-stories/Schoolsnapshots/Kaimai-School

Robinson, K., \& Aronica, L. (2015). Creative schools: The grassroots revolution that's transforming education. New York: Viking.

Rogoff, B. (1995). Observing sociocultural activity on three planes: Participatory appropriation, guided participation, and apprenticeship. In J. V. Wertsch, P. del Rio, \& A. Alvarez (Eds.), Sociocultural studies of mind (pp. 139-164). https://doi.org/10.1017/CB09781139174299.008

Rogoff, B. (2003). Cultural Nature of Human Development. Retrieved from http://ebookcentral.proquest.com/lib/vuw/detail.action?docID $=272865$

Sahlberg, P., \& Doyle, W. (2019). Let the children play: How more play will save our schools and help children thrive. New York: Oxford University Press. 
Sherley, B. M. (2011). Kindergarten and new entrant teachers' beliefs and practices in mathematics teaching and learning (Doctoral thesis, Victoria University of Wellington, Wellington, New Zealand). Retrieved from http://hdl.handle.net/10063/1692

Smith, P. K., Cowie, H., \& Blades, M. (2011). Understanding children's development (5th ed). Chichester, West Sussex: Wiley.

Suggate, S., \& Reese, E. (2012). Contemporary debates in childhood education and development. Retrieved from http://ebookcentral.proquest.com/lib/vuw/detail.action?docID $\equiv 982039$

Sutton-Smith, B. (1997). The ambiguity of play. Cambridge, Mass: Harvard University Press.

Van Oers, Bert, \& Duijkers, D. (2013). Teaching in a play-based curriculum: Theory, practice and evidence of developmental education for young children. Journal of Curriculum Studies, 45(4), 511-534. https://doi.org/10.1080/00220272.2011.637182

Vygotsky, L. S. (1978). Mind in society: The development of higher psychological processes (Nachdr.). Cambridge, Mass.: Harvard Univ. Press.

Vygotsky, L. S. (2016). Play and its role in the mental development of the child. International Research in Early Childhood Education, $7(2), 3-25$.

Walker, K. (2011). Play matters: Investigative learning for preschool to grade 2 (2nd ed). Camberwell, Victoria: ACER Press.

Wallerstedt, C., \& Pramling, N. (2012). Learning to play in a goaldirected practice. Early Years, 32(1), 5-15. https://doi.org/10.1080/09575146.2011.593028

Wallis, N. (2019, June). Teen Brain. Presented at the Seminar at Raroa 
Normal Intermediate School, Wellington.

Weisberg, D. S., Hirsh-Pasek, K., \& Golinkoff, R. M. (2013). Guided play:

Where curricular goals meet a playful pedagogy. Mind, Brain, and Education, 7(2), 104-112. https://doi.org/10.1111/mbe.12015

Weisberg, D. S., Hirsh-Pasek, K., Golinkoff, R. M., Kittredge, A. K., \& Klahr,

D. (2016). Guided play: Principles and practices. Current

Directions in Psychological Science, 25(3), 177-182.

https://doi.org/10.1177/0963721416645512

Whitebread, D. (2018). Play: The new renaissance. International Journal of Play, 7(3), 237-243.

https://doi.org/10.1080/21594937.2018.1532952

Wood, D., Bruner, J. S., \& Ross, G. (1976). The role of tutoring in problem solving. Journal of Child Psychology and Psychiatry, 17(2), 89100. https://doi.org/10.1111/j.1469-7610.1976.tb00381.x

Wood, E. (2013). Play, learning and the early childhood curriculum (3rd ed.). London ; Thousand Oaks, CA: Sage Publications.

Wu, S.-C. (2015). What can Chinese and German children tell us about their learning and play in kindergarten? Journal of Research in Childhood Education, 29(3), 338-351.

https://doi.org/10.1080/02568543.2015.1042125

Yogman, M., Garner, A., Hutchinson, J., Hirsh-Pasek, K., Golinkoff, R. M., Committee on Psychosocial Aspects of Child and Family Health, \& Council on Communications and Media. (2018). The Power of Play: A Pediatric Role in Enhancing Development in Young Children. Pediatrics, 142(3), e20182058. https://doi.org/10.1542/peds.2018-2058

Zosh, J. N., Hopkins, E. J., Jensen, H., Liu, C., Neale, D., Hirsh-Pasek, K., ... Whitebread, D. (2017). Learning through play: A review of the evidence [White paper]. DK: The LEGO Foundation. Retrieved 
from https://www.legofoundation.com/media/1063/learning-

through-play web.pdf 


\section{Appendix A}

\section{Semi-structured interview schedule for teachers}

Name:

Year Level/s teaching:

School:

Length of time teaching/time teaching junior students:

Brief description of school (decile, urban/rural, roll, other notable features):

Please tell me about your journey into play-based learning (PBL).

Probes:

What motivated you to make the transition to PBL?

What defines a play-based environment in your opinion? How much, and in what ways, do you engage in the play?

How does it run in your school?

What changes in your practice have you made as a result of using PBL in your classroom? Why?

Has this experience changed the way you see yourself as a teacher? In what ways?

Has this experience changed the relationships you have with students?

Parents? Colleagues? School leaders? How/in what ways? 
Has this experience changed your view/understanding/use of the NZ Curriculum documents? How/in what ways?

How do you measure progress? What forms of assessment do you use? What has changed in your assessment practices?

What play-based learning training or professional development have you participated in? 


\section{Appendix B}

\section{Observation schedule for classroom observations}

Date:

Time:

School:

Teacher being observed:

Observation: 12 (circle)

Sketch of classroom set up (include different areas in the space, furniture, storage, equipment, etc.)

Description of classroom environment (including type of classroom Single cell/ILE, number of students, ages of students, resources available, storage etc) 
Running Record of teacher interactions with students. (Take note of type of interaction, e.g., giving directions, comments, questions, prompts, redirections etc.)

\begin{tabular}{|l|l|}
\hline Time & Running Record of teacher interactions \\
\hline & \\
\hline & \\
\hline & \\
\hline & \\
\hline & \\
\hline & \\
\hline
\end{tabular}

